\title{
A review of mass concentrations of Bramblings Fringilla montifringilla: implications for assessment of large numbers of birds
}

\author{
En översikt om massförekomster av bergfinkar Fringilla \\ montifringilla: implikationer för antalsbedömningar av \\ stora mängder fåglar
}

\author{
Tomas Svensson \\ Skånes Ornitologiska Förening, Gustavsgatan 25, 21611 Limhamn, Sweden | lasertomas@gmail.com
}

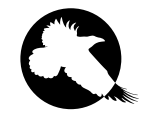

MASS CONCENTRATIONS of birds, or the lack thereof, is a phenomenon of great ecological and domestic significance. Apart from being and indicator of, e.g., food availability, ecological change, and population size, it is also a source of conflict between humans and birds. By attracting the attention of the public-either as a spectacular phenomenon or as an unwelcome pest-they also form the public perception of birds and their abundance. In the context of the mass concentration of Bramblings Fringilla montifringilla in Sweden during the winter 2019-2020, this work reviews the literature on this striking phenomenon. I found that winter roosts amount to about one million birds per hectare of roost area, but the variation between reports is significant. There is support for roosts of up to around 15 million Bramblings, but much larger numbers are frequently cited in the literature. I discuss difficulties related to the assessment of mass concentrations, and argue that reports of very large numbers should always be carefully scrutinized.

Keywords: beech mast year | bird counting | communal roosting | European beech Fagus sylvatica | flock size | irruptive migration | winter ecology 


\section{Introduction}

The occurrence, or absence, of large flocks of birds is linked to factors such as population size, food abundance, and food distribution and can therefore carry important information on the status of, and changes in, the environment (Hémery \& Pascaud 1981, Møller \& Laursen 2019). Mass concentrations of birds is also an important source of conflicts with humans. As an example, tens of millions of Red-billed Queleas Quelea quelea are, due to their impact on farming, annually poisoned or blown up in Sub-Saharan Africa (McWilliam \& Cheke 2004). Similarly, various American troupials and allies (Icteridae)-most notably the Red-winged Blackbird Agelaius phoeniceus-aggregate in huge flocks and are considered a major pest in North America (Linz et al. 2017). The European Starling Sturnus vulgaris, one of only three bird species on the IUCN list of the world's most invasive species (Lowe et al. 2000), is yet another interesting example. European Starlings are considered a serious problem in many countries over several continents, causing, for example, damage on fruit and berry farming and spread of disease by shedding Salmonella enterica and Escherichia coli in the context of animal farming (Feare et al. 1992, Homan et al. 2017).

The species mentioned above are examples of birds that are reported to gather in millions. Such mass concentrations of birds are rare, and no more than around 50 of the world's near 11,000 bird species have been reported to reach seven-digit numbers (see e.g. Møller \& Laursen 2019). As it is well known that counting large numbers of birds is extremely difficult, and since it matters if a bird count is 100,000 or $1,000,000$ (implying a factor of ten difference in potential crop damage or population size), it is well worth looking closer into the ways mass concentrations are counted and accounted for.

In this work, I take a closer look at the Brambling Fringilla montifringilla (Figure 1) and its mass appearances in Europe during European beech Fagus sylvatica mast years. The Brambling is the species in Europe that appears in largest flocks and is thus an interesting case study for discussing number estimates. The work is the result of an attempt to put the mass concentration in southern Sweden during the 2019-2020 winter into an international and historical perspective. After a description of the 2019-2020 events, I present a literature review and discuss counting methods. The focus is on

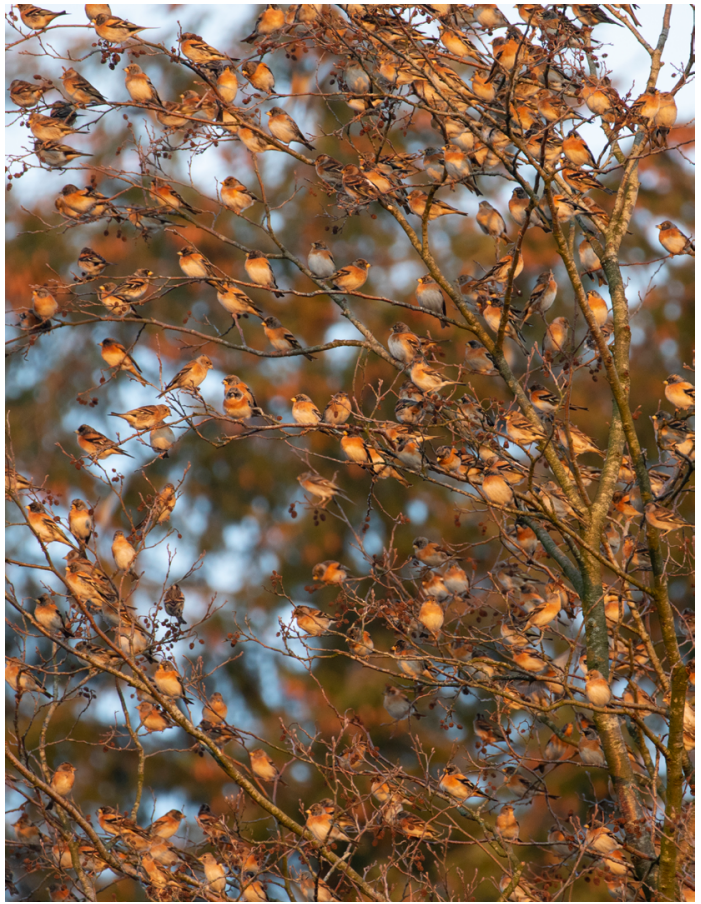

FIGURE 1. Bramblings Fringilla montifringilla can display mass appearances during European beech Fagus sylvatica mast years. Here a flock perched in a bare black alder Alnus glutinosa, before entering their roost at Lake Rössjön, Sweden, 6 February 2020.

- Bergfinkar Fringilla montifringilla kan uppvisa massuppträdanden under år då boken Fagus sylvatica har god ollonproduktion. Här en flock i en kal klibbal Alnus glutinosa alldeles intill den granplantering som utgjorde sovplats. Fotografiet är taget 6 februari i samband med inflygning till sovplatsen vid Rössjön.

number estimation and roost density, and my main aim is to problematize the counting and reporting of large numbers of birds. For other aspects of the fascinating phenomenon of communal roosting of Bramblings, I refer the reader to the existing literature. There are numerous ambitious studies on the topic, covering everything from the relation to food abundance and snow cover (Jenni \& Neuschulz 1985, Jenni 1987), the origin of birds and ring recoveries (Schifferli 1953, Jenni 1982, Kjellén \& Lindström 1993, Browne \& Mead, 2003), the roost microclimate and communal roosting aspects (Jenni 1991, 1993, Khil et al. 2011, Arizaga et al. 2012, Zabala et al. 2012), and the foraging patterns and energy needs (Granvik 1916a, Hémery \& Le Toquin 1975a, 1976, Francois 1978, Nardin \& Brauchle 1979, Nardin \& Nardin 1985, Jenni \& Jenni-Eeiermann 1987, Kjellén 
\& Lindström 1993, Khil et al. 2011), to the behaviour of raptors in the vicinity of roosts (Jenni 1993, Khil et al. 2011, Zuberogoitia et al. 2012).

\section{Brambling ecology and behaviour}

The Brambling is one of the most numerous birds in the world. It breeds across northern forests of Europe and Asia, with a breeding range ranging all the way from Norway to eastern Siberia. The global population, which seems to be under moderate decline, is estimated to $100-200$ million pairs, while the European population is limited to around $15-25$ million breeding pairs (Birdlife International 2020). The species is migratory, but irruptive, i.e. exhibiting significant variation in migration patterns (see e.g. Newton 2006, 2012). While it is said to mainly migrate during night (Newton 1972), some 100,000 Bramblings are counted annually in Falsterbo, while leaving southern Sweden in daylight. On average almost one million finches are recorded in the standardized migration count, but chaffinch Fringilla coelebs is the dominating species, with Bramblings typically making up $5-25 \%$ of the flocks (N. Kjellén, pers. comm.). While few ornithologists appear to have heard Bramblings during the night, data from lighthouse strikes suggests that the Brambling indeed is a nocturnal migrant. Between 1886 and 1939, in a longterm Danish study, 1,568 Bramblings were collected at Danish lighthouses following collisions, to be compared with, e.g., 532 Chaffinches and 1,569 Willow Warblers Phylloscopus trochilus (Hansen 1954). Alerstam (1993) also noted Bramblings leaving Sweden, heading out over the Baltic sea, at dusk.

In essence, the European Bramblings move towards the southwest until they find sufficient food resources (Jenni 1987). Many end up in the vast beech forests of Central Europe, but the migration patterns vary significantly from year to year. In Sweden, an often-mentioned example is an individual ringed when wintering in Halland (southwest Sweden) in January 1965 and recovered two years later wintering in Caucasus (Kjellén \& Lindström 1993, Bird Ringing Centre, Swedish Museum of Natural History 2020). Other ringing recoveries include a bird ringed in Blekinge (southeast Sweden) in January 1986, found dead the following year in southwest France, and a bird ringed in Småland (south Sweden) in January 1955, killed in Spain in November the same year (Bird Ringing Centre, Swedish Museum of Natural History 2020). Swiss ring recoveries show that central Europe is also reached by Bramblings with an origin east of the Ural Mountains (Jenni 1982). This nomadic character, promoting continuous gene flow between distant populations, is considered a reason why the species is monomorphic, despite its wide breeding range (Kjellén \& Lindström 1993).

When it comes to food, the Brambling is an omnivore, although rather specialized. During breeding, the Brambling has been found to rely on larvae of the autumnal moth Epirrita autumnata, and its breeding success correlates with the strong cyclical fluctuations of this moth species (Lindström et al. 2005, Newton 2007). During winters, a strong inclination for communal roosting (cf. Beauchamp 1999) results, albeit sporadically, in one of the most spectacular mass concentrations of animals in Europe. Nuts of the European beech is the primary winter food of Bramblings, and during beech mast years the abundance of food allows them to aggregate and form roosts comprising millions of birds (see e.g. Jenni 1987). The birds typically settle in coniferous forest sections in the vicinity of large beech forests (Jenni 1991). Interestingly, in a limited period of time 1960-1980, corn fields in France also played an important role (this is discussed further below, see also Hémery \& Le Toquin 1975a, Dubois et al. 2008). The same patches can be used for months if food supplies and snow coverage allow. The distribution of European beech is shown in Figure 2, giving a rough indication of where Bramblings can be expected to winter in large numbers in Europe.

A single Brambling requires some $25-30 \mathrm{kcal}$ per day (Hémery \& Le Toquin 1975a, 1976, Kjellén \& Lindström 1993), corresponding to about $8 \mathrm{~g}$ of beech seeds (around 40 seeds, or a fourth of their body weight). This is based on published energy values for tree seeds: the nutritive material (seed excluding coat) of a seed carries $7 \mathrm{kcal}$ per $\mathrm{g}$ dry weight and the dry weight of nutritive material per seed is around $0.12 \mathrm{~g}$ (Grodziński \& Sawicka-Kapusta 1970, Nilsson 1979), resulting in around $0.84 \mathrm{kcal}$, or $3.5 \mathrm{~kJ}$, per seed. Assuming $83 \%$ energy utilization (Kjellén \& Lindström 1993), this means that a single Brambling requires some 40 seeds per day $(27.5 \mathrm{kcal} /$ day $/(83 \% \times 0.84 \mathrm{kcal} / \mathrm{seed}) \approx 40$ seeds $/$ day $)$. Since the fresh weight of a whole seed is around $0.2 \mathrm{~g}$, this corresponds to $8 \mathrm{~g}$. These energy considerations 


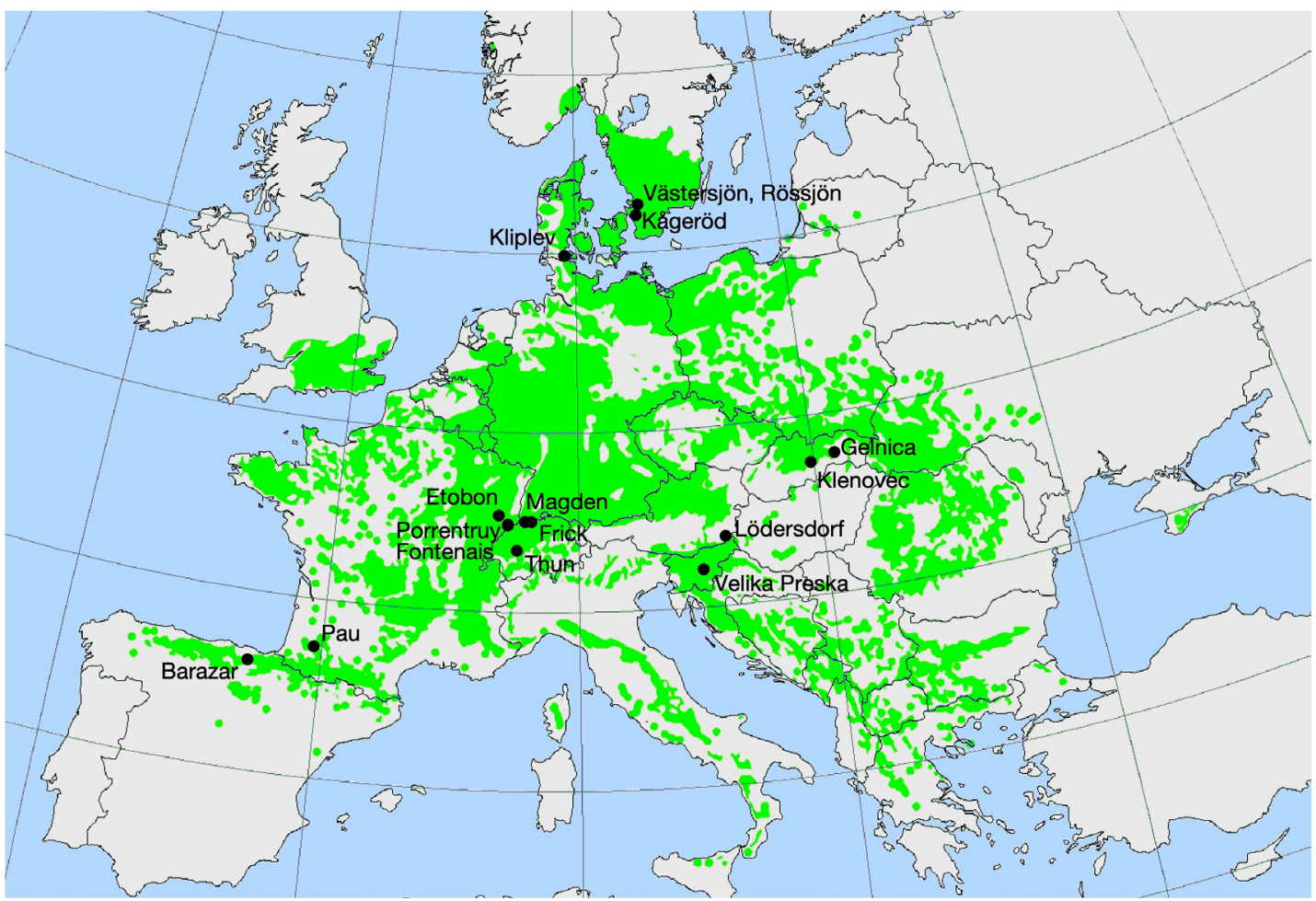

FIGURE 2. Distribution map of European beech Fagus sylvatica in Europe, adapted from von Wühlisch (2008). As beechnuts is the primary winter food of Bramblings Fringilla montifringilla, the map indicates where they can be expected to winter in large numbers. Winter roosts that have been described in detail, constituting the core of this study, are specified (cf. Table 1). Note that the distribution of Oriental beech $F$. orientalis, e.g. in Turkey and the Caucasus, is not included in this map.

- Utbredningskarta för bok Fagus sylvatica i Europa, anpassad från von Wühlisch (2008). Eftersom bokollon är bergfinkens Fringilla montifringilla huvudsakliga vinterföda visar kartan var arten kan förväntas övervintra i stora antal. Övervintringsplatser med massuppträdanden som beskrivits $i$ detalj, vilka utgör kärnunderlaget för denna studie, indikeras på kartan (jfr tabell 1). Notera att utbredningen i bl. a. Turkiet och Kaukasus av en annan bokart, F. orientalis, inte inkluderats $i$ kartan.

indicate that one million Bramblings consume on the order of 8 tons of beech seeds per day, summing up to around 1,000 tons for a four-month wintering stay. During a mast year, the beechnut production can be well above 1 ton/ha (Kjellén \& Lindström 1993, Övergaard et al. $2007 \mathrm{~b}$, Övergaard 2010). Given than the Bramblings can fly up to at least $40 \mathrm{~km}$ from a winter roost (Mühlethaler 1952, Hémery \& Le Toquin 1975b, Francois 1978, Jenni 1984, Chalverat 2003, Khil et al. 2011), the accessible area is around 500,000 ha. The fraction of beech forest in that area can thus even be relatively low (even below 1\%o) and still support millions of Bramblings for several months.

An interesting aspect of mass roosting is the massive amount of faeces deposited in the roost area. Not only does it produce a strong odour, but it also affects the ecosystem (Chalverat 2003). In 2000, as an example, a new species of fungus was discovered in the aftermath of a huge Brambling roost and was named Pseudombrophila stercofringilla after the bird excrements (Dougoud 2001). Still, the impact of Brambling roosts on forest ecosystems should be small compared to how the enormous Passenger Pigeon Ectopistes migratorius population-a species also specialised on tree seeds such as beech mast-affected forest ecology in North America (see e.g. Bucher 1992, Ellsworth \& McComb 2003). In general, the knowledge of ecological functions of birds is far from complete (Şekercioglu 2006) and the role Bramblings have played in European beech forests, if any, is not clear.

Historically, the appearance of millions of Bramblings was often seen as a bad omen, as a sign of war, 
starvation, or pest (Holmgren 1866, Granvik 1916a, Haikos 1950). Today, it is more of an attraction for nature lovers. However, it is worth keeping in mind that species for which a significant part of the population accumulates in limited areas are very vulnerable to, for example, hunting and poisoning. The Passenger Pigeon is a famous example, and a more contemporary example of this kind of vulnerability is the dramatic decline of the Yellow-breasted Bunting Emberiza aureola. Once superabundant, rampant trapping and eating has brought the population of this species down to around $10 \%$ of what it was only a few decades ago (Kamp et al. 2015).

\section{The mass concentration in Sweden 2019-2020}

After an extremely warm and dry summer 2018 and good conditions for European beech flowering during 2019, the beechnut crop of 2019 turned out to be enor- mous. Although the quantitative beech mast counts, operated by the Swedish University of Agricultural Sciences, unfortunately was discontinued a few years ago, there is no doubt that 2019 was an extreme mast year. I made rough counts, which indicated that a single large beech tree could carry on the order of 100,000 shells (cupules), corresponding to 200,000 seeds. Assuming that one hectare of beech forest is equivalent of 100 large trees, the seed production could be on the order of 20 million per hectare. As a comparison, the highest local beech mast production during the beech mast survey 1989-2006 amounted to 14 million/ha (Övergaard et al. 2007a, Övergaard et al. 2007b; Övergaard 2010). Furthermore, Prof. Sven G. Nilsson has conducted semi-quantitative monitoring of beech mast in Sweden since 1971, ranking the crop from o (no crop) to 5 (massive crop), and reports that there has not been a year in this series with as much beech mast as 2019 (S. G. Nilsson, pers. comm.). Without standardized quantita-

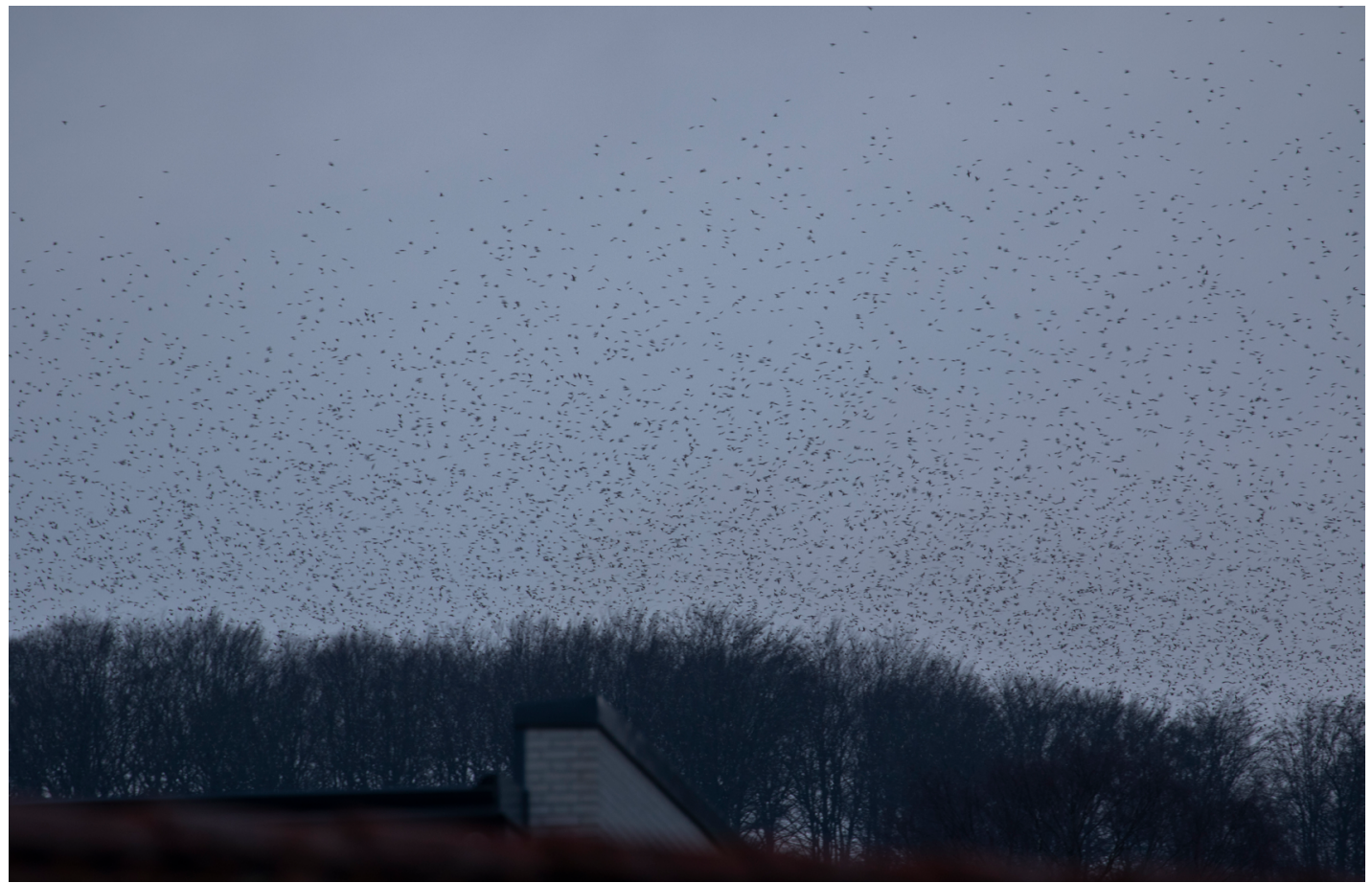

FIGURE 3. A stream of Bramblings Fringilla montifringilla passing Båstad, Sweden, 22 December 2019 at a distance of 1 km. Manual marking of the individual birds revealed that this photo contains around 8,260 birds, which is the basis for calculations arriving at a stream intensity of 1,900 birds per second (see text).

- En strid ström bergfinkar Fringilla montifringilla passerar Båstad 22 december 2019 på en kilometers avstånd. Markeringar för hand av enskilda fåglar avslöjade att detta foto innehåller ungefär 8260 exemplar, vilket utgör grunden för beräkningar som resulterar i ett flöde om 1900 fåglar per sekund (se text). 


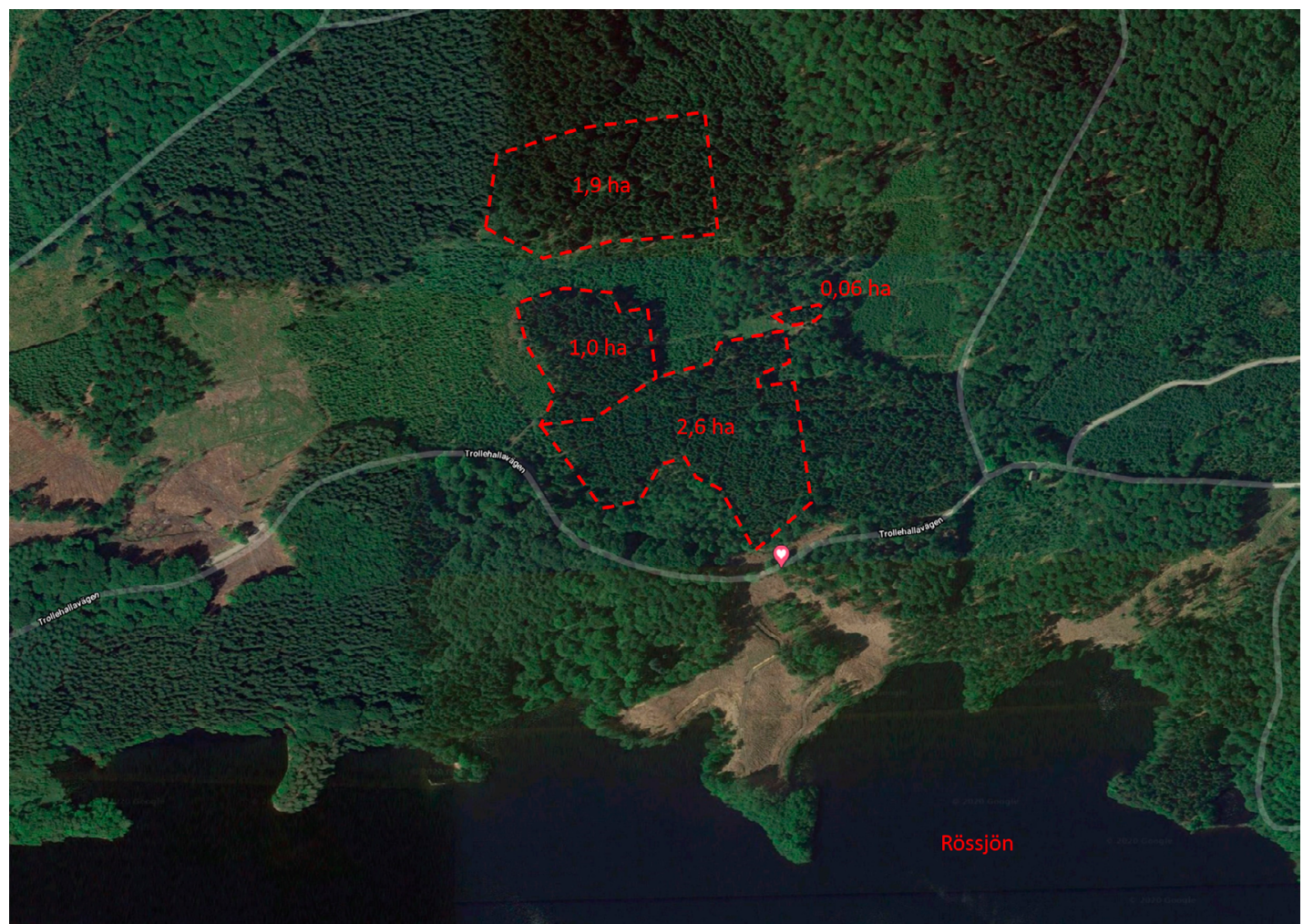

FIGURE 4. Annotated map showing the 5.6 ha roost area that appeared to be used by Bramblings Fringilla montifringilla simultaneously in early January 2020 (from Google Maps). The area was demarcated based on droppings and evening sound.

- Annoterad karta som visar det område om 5,6 ha, som verkade användas simultant av bergfinkar Fringilla montifringilla i början av januari 2000 (från Google Maps). Området avgränsades med ledning av träck på marken och skymningsljud.

tive data, it is however difficult to know exactly how the 2019 mast year compares to other mast years. In addition to the rich beech crop, it is also interesting to note that the Brambling seems to have had a good breeding season in Sweden. The LUVRE project (https://www. luvre.lu.se), monitoring birds in the northern birch Betula sp. forests since the 1960 s, reports their highest number of ringed juvenile Bramblings since the ringing started in 1983, and the third highest reproduction in terms of juveniles per adult ( $\AA$. Lindström, pers. comm.).

It became clear in November-December 2019 that masses of Bramblings ended their migration in southern Sweden, taking advantage of the food abundance. Large flocks were reported from various areas of Scania (Skåne). A massive afternoon movement over the city of Båstad 22 December 2019 (Figure 3, Video 1), witnessed by me and my brother Stefan Svensson, involved millions of birds and indicated that a roost could be found in the area. I found the roost on 4 January 2020 (Svensson 2020) on the south-facing slopes of the Hallandsås Horst, just north of Lake Rössjön (Figure 4, Video 1). Additional photos and videos can be found at https://bit.ly/3×3QyjK. I estimated the roost area to 5.6 ha via night-time sounds in combination with visual inspection of excrement layers and their boundaries (droppings), together with areal analysis using map tools supplied by Lantmäteriet (www.lantmateriet. se). A map of the roost area is shown in Figure 4. The roost consisted of, respectively, approximately 2.6 ha of 31-year-old and 3.o ha of 39-year-old plantations of Norway spruce Picea abies. The younger parts were dense with about $2 \mathrm{~m}$ between trees, while the older parts were thinned out with a 4-5 $\mathrm{m}$ distance between trees. Tree height ranged from 10 to $25 \mathrm{~m}$. Figure 5 shows a view from the roost perimeter.

Employing a simple square grid model on the 


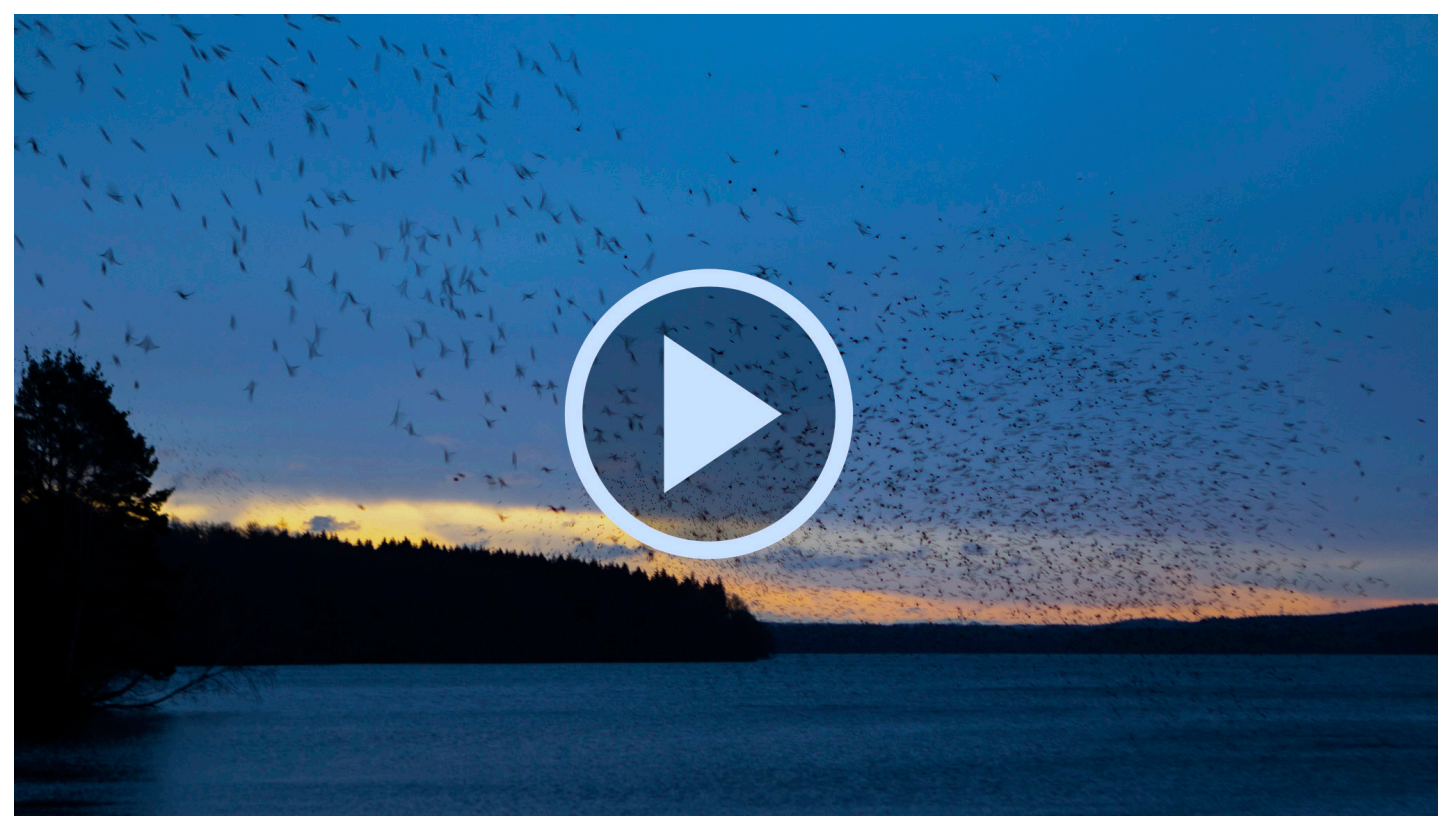

VIDEO 1. 59-second video collage of the 2019-2020 mass concentrations of Bramblings Fringilla montifringilla in southern Sweden. Click the video and answer yes to any security prompts (requires an updated version of Acrobat Reader). The video is also available at https://flic.kr/p/2kUv7he. - Videokollage om 59 sekunder, som visar massförekomsten av bergfinkar Fringilla montifringilla under vintern 2019-2020 i Sverige. Klicka på videon och svara ja på eventuella säkerhetsfrågor (kräver en uppdaterad version av Acrobat Reader). Videon är också tillgänglig på https://flic.kr/p/2kUv7he.

above-mentioned tree spacings, and reducing the count by $10 \%$ to account for small openings and forest roads, this results in the following rough tree count estimate:

$$
N_{\text {trees }}=0.9 \times\left(2.6 \times(100 / 2)^{2}+3.0 \times(100 / 4.5)^{2}\right) \approx 7,000 \text { trees }
$$

On-site counting at the 2019-2020 site was very difficult, as it was impossible to get a good overview of the roost. Monitoring morning lifts or evening fly-ins was thus not easily done. The best estimate is most likely that from Båstad on 22 December 2019, assuming that all of the birds passing there were headed for the same roost and that most of the roosting birds had spent the day in the same area. The flow over Båstad was overwhelming even to rather experienced migration counters. From analysis of photos, the front of Bramblings was over one kilometre wide at its peak intensity.

Thousands of Bramblings were in the binocular field of view and passed within a matter of seconds. I reached a number estimate first after an analysis based on photographs and timing of the movement. Our field notes state that the movement occurred during c. 5 minutes around 13:40, and then during
45 minutes from 14:55 to $15: 40$ (it was almost dark in the end, so the Bramblings seem to have been late this day-the sunset was at 15:33). I analysed a photo of a distant streak (where birds were caught from the side, simplifying analysis; Figure 3) taken with a Canon EOS7D with EF10o-40o mm f/4.5-5.6L IS II USM at its maximum focal length, giving a $3.23^{\circ}$ horizontal field-of-view. From the size of the birds (o.15 $\mathrm{m}$ physically, and around 15 pixels on the 5,427 by 3,648 pixel sensor), I estimated this stream to be around $0.15 / \tan \left(15 \mathrm{px} / 5,427 \mathrm{px} \times 3.23^{\circ}\right) \approx 1 \mathrm{~km}$ away. Via careful manual marking of the individual birds, I established that the photo contains around 8,260 birds. The camera field-of-view at $1 \mathrm{~km}$ is around $56 \mathrm{~m}$. Radar measurements have shown that Bramblings fly at $15 \mathrm{~m} / \mathrm{s}$ (Alerstam et al. 2007) and after accounting for around $2 \mathrm{~m} / \mathrm{s}$ headwind (as reported by the closest wind station), the 8,260 birds should pass the field of view in around $56 / 13 \approx 4.3 \mathrm{~s}$. This corresponds to an intensity of around 1,900 birds passing per second $\left(1,900 \mathrm{~s}^{-1}\right)$.

At peak intensity we estimated that the total intensity should be two to three times of that. An analysis 


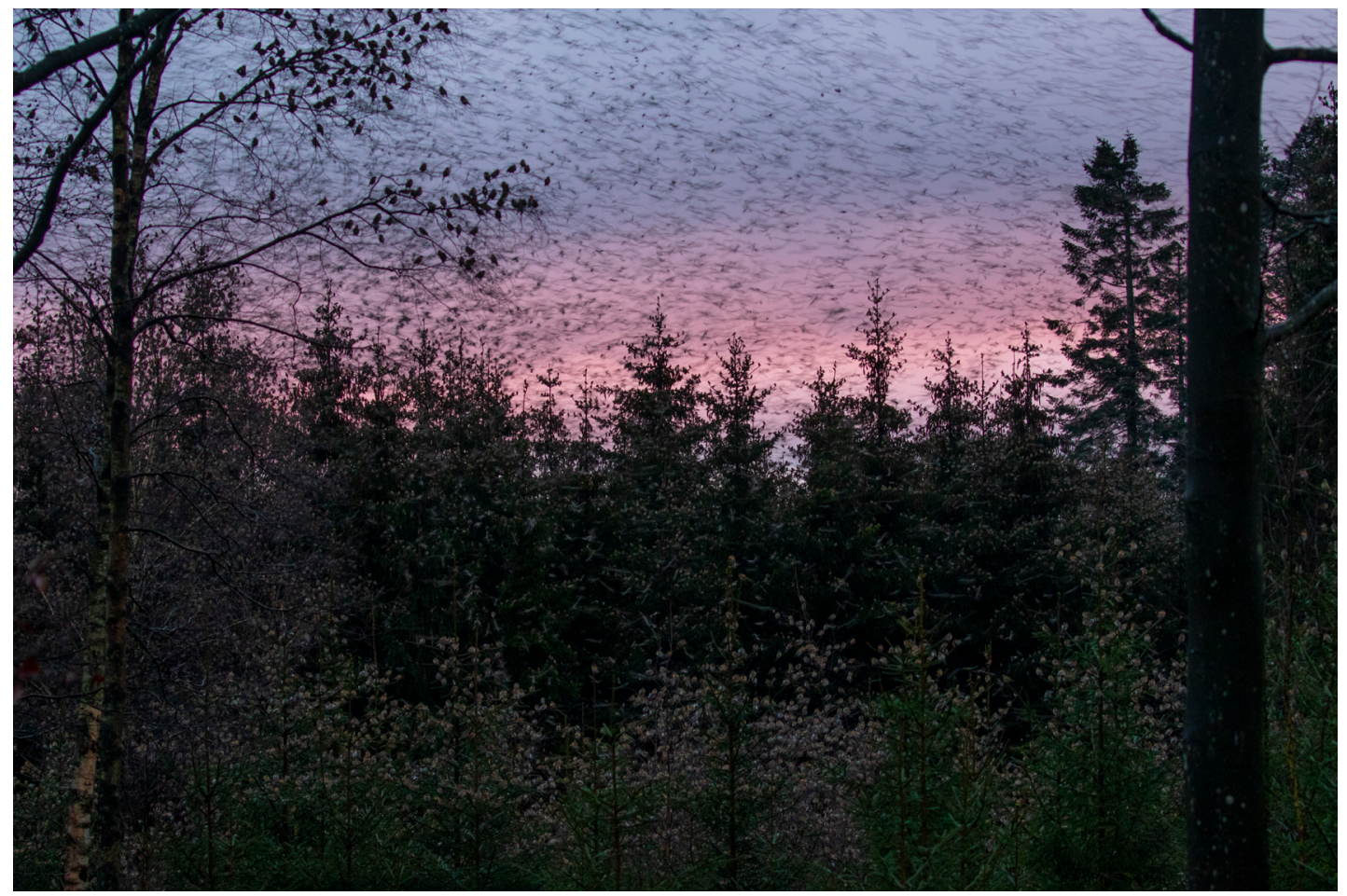

FIGURE 5. Evening at the Brambling Fringilla montifringilla roost at Lake Rössjön, Sweden, on 4 February 2020. View towards the northern side of the younger section.

- Kväll vid bergfinkarnas Fringilla montifringilla sovplats vid Rössjön 4 februari 2020. Fotot visar en vy mot den norra sidan av ett område med yngre skog.

of a photo taken at a time when we considered the migration as "dead", revealed an intensity of $300 \mathrm{~s}^{-1}$ (see Figure 6).

The numbers are breathtaking. In Falsterbo, with its annual standardised migration counts, finches are typically counted at a few thousands per minute on a good day. We (the author and Stefan Svensson) judged that the most intense period lasted around 20 minutes, and that the total amount of birds could be estimated from 30 minutes with 1,000 birds/s and 20 minutes with 5,000 birds/s, resulting in 7.8 million birds. As a lower bound, and since field notes are imperfect and we did not take photos systematically throughout the Brambling passage, we propose to use 40 minutes as total duration and restricting the most intense period to 10 minutes and 4,000 birds/s. This approximate lower bound amounts to 4.2 million birds. As an upper bound, maybe 30 minutes with $1,500 \mathrm{birds} / \mathrm{s}$ and 20 minutes with 6,00o birds/s is conceivable, summing up to 9.9 million. A reasonable, albeit rough, range for the number of Bramblings involved in this movement is thus 4-10 million. As a comparison, during an onsite visit together with Nils Kjellén and Ola Elleström on 4 January 2020, we very roughly estimated that we witnessed, visible from our side of the roost area, a flyin intensity of around 2,000 birds/s during 40 minutes, summing up to around 5 million birds. The sound and visual experience was stunning.

Some efforts were also made to estimate the number of birds roosting per tree, but no firm conclusion could be reached. Infrared photographs indicate that ten birds easily can sit on a single twig during the night (see Figure 7), and observations and photographs taken at dusk indicate on the order of 1,000 birds fitting in a single spruce tree. Still, the number of birds per tree during night remains an open question and more efforts are needed to elucidate this matter. As movements seem occur after dark, and since the Bramblings are disturbed when approached, installation of infrared cameras in the roost may be an interesting approach. 


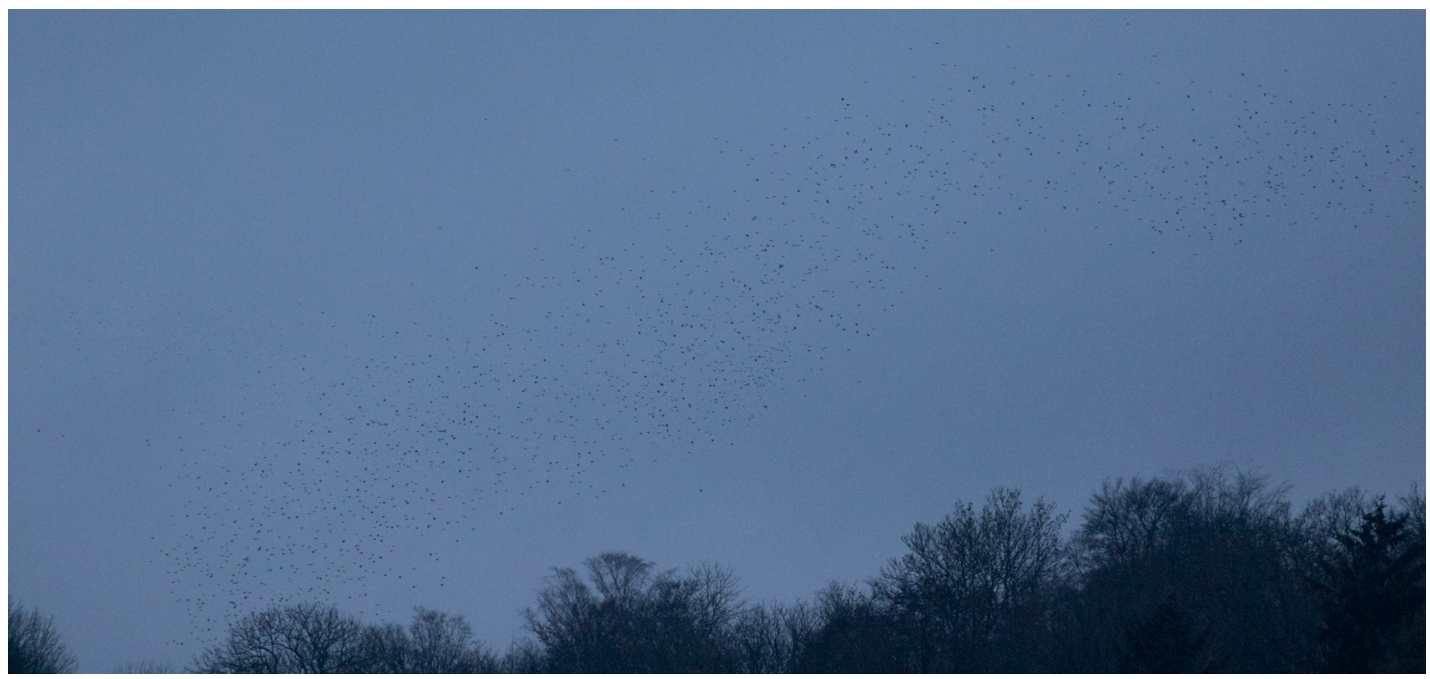

FIGURE 6. Photo taken at a time when the movement of Bramblings Fringilla montifringilla was considered to be nearly "dead", Båstad, Sweden, 22 December 2019. The photo was taken 15:33, but the intensity increased again after this dip. The movement ended at around 15:40. Excluding a faint stream in the background, the photo contains around 1,575 birds (manually marked) flying at a distance of around $1.2 \mathrm{~km}$. The corresponding instantaneous intensity is around 300 birds per second.

- Ett foto som visar när bergfinkarnas Fringilla montifringilla förflyttning i sammanhanget betraktades vara nästan "död". Fotot är taget klockan 15:33 den 22 december 2019 i Båstad, varefter intensiteten ökade igen för att sedan avta och helt sluta runt 15:40. Bortsett från en svagt tecknad flock i bakgrunden innehåller detta foto ca 1575 fåglar (markerade för hand) som flyger på ett avstånd om ca 1,2 km. Detta motsvarar en intensitet runt 300 fåglar per sekund.

Although Bramblings winter in Sweden regularly, few Brambling winter roosts have been found. Prior to the roost described above, only three roosts have been located and described in detail (Granvik 1916, Mathiasson 1960, Kjellén \& Lindström 1993). One of these roosts was found in 1993 very close to the location described above: just north of the neighbouring Lake Västersjön, on the same south-facing slopes (Kjellén \& Lindström 1993). Another roost was found was found some $36 \mathrm{~km}$ south of these locations during the 1915-1916 winter (Granvik 1916). This part of Scania has vast European beech forests and is relatively sparsely populated. It is therefore likely that even rather large roost can be overlooked. As an example, during the research for this article, I stumbled across a YouTube video filmed by fishermen in February 2012, showing enormous flocks of Bramblings flying over Lake Västersjön (Hafström 2012), whereas no roost was found this year. There are also years when ornithologists have reported flocks comprising a million birds in various parts in southern Sweden, yet without any roosts having been located.

Given the climate change that is upon us, it can be expected that Bramblings will winter in southern Swe- den in increasing numbers. The 2019-2020 winter was, in fact, according to standard meteorological definitions, not a winter season at all and the average temperature was $4^{\circ} \mathrm{C}$ above normal (SMHI 2020). Scania is rarely covered in snow nowadays and the frequency of beech mast years has increased in recent years (Övergaard et al. 2007a), although long-term variability also must be considered (Drobyshev et al. 2014).

\section{A review of reports on mass concentrations}

It is sometimes argued that the Brambling is the bird that gathers in the largest numbers of all (Newton 1998). A better guess is perhaps the Red-billed Quelea, which is reported to occur in numbers exceeding 100 million (Hancock \& Weiersbye 2015). Several other bird species are also potential "records holders" (see e.g. Møller \& Laursen 2019), but given the challenges in bird counting, it appears very difficult to settle such a question. If including extinct species, the Passenger Pigeon will make settlement easier: the species has even been claimed to occur in flocks exceeding a billion birds 
(a sad but important reminder that what is common today may go extinct more rapidly than we expect, $\mathrm{cf}$. Murray et al. 2017).

Turning back to Bramblings, gatherings of millions are reported far from annually. This is expected, since very large roosts appear to form only during beech mast years. Throughout the years, however, numerous accounts of the phenomenon are available thanks to authors from several European countries. Unfortunately, many reports neither provide details on how numbers were estimated, nor details regarding roost area. Many authors express how difficult it was to count properly and, in many cases, there are massive disagreements about the actual number of birds involved. This review aims at elucidating this matter and the main focus is therefore on reports that give details on number estimations and roost areas.

\section{APPROACHES FOR NUMBER ESTIMATION}

Three different approaches to number estimation were encountered in these reports:

A. Stream intensity and time, $N=I \times T$

B. Flock volume and density,

$$
N=B \times H \times L \times \rho=B \times H \times v T \times \rho
$$

C. Tree count and birds per tree,

$$
N=N_{\text {trees }} \times N_{\text {birds }} \text { per tree }
$$

In method $A$, the number of birds $N$ is reached by estimating the intensity of birds I passing an observer (birds/s) in combination with duration (time) $T$ of the passage of that intensity. Since intensity will fluctuate, new estimates should ideally be done continuously. The intensity can either be estimated directly (instantaneously) by the observer, or it can be done afterwards via analysis of photographs. Method B, on the other hand, focuses on flock volume (width $W$, height $H$ and length $L$ ) and bird density $\rho$ (birds $/ \mathrm{m}^{3}$ ), where flock length is reached by assuming a certain ground speed $v$. Many works assume that Bramblings fly at $60 \mathrm{~km} / \mathrm{h} \approx 16.7 \mathrm{~m} / \mathrm{s}$, while radar measurements indicate that their ground speed rather is $15 \mathrm{~m} / \mathrm{s}=54 \mathrm{~km} / \mathrm{h}(\mathrm{Al}-$ erstam et al. 2007). This inherent overestimation of $10 \%$ should of course be avoided, even though it in most cases will be negligible compared to other uncertainties. Method C is very different: instead of counting flying birds, the focus is on roost parameters. The number is reached by multiplying the number of trees in the roost by the average number of birds per tree.

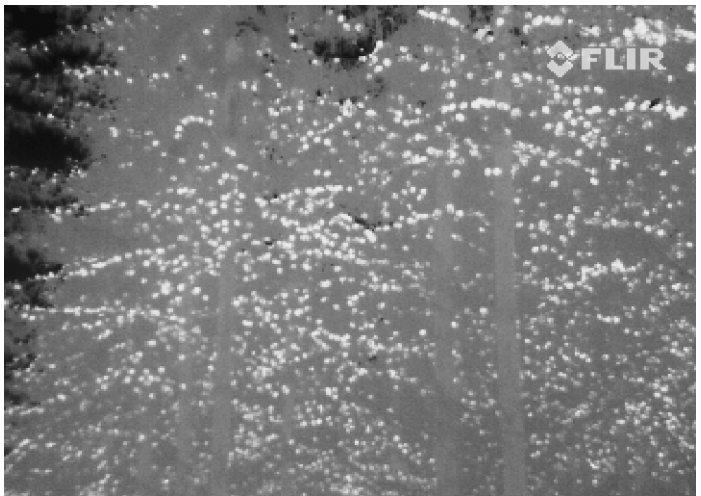

FIGURE 7. Thermal photograph taken with a hand-held FLIR Scout TS24 Pro. The photo was taken just outside the Brambling Fringilla montifringilla roost perimeter in the dark. It was impossible to walk further without causing chaos. The slightest sound or light increased the chattering and made many birds take off with the sound of storm winds.

- Foto från en handhållen värmekamera FLIR Scout TS24 Pro som visar bergfinkar Fringilla montifringilla i träd strax utanför den egentliga sovplatsen. Trots att det var mörkt var det omöjligt att gå närmare utan att orsaka kaos, då minsta ljud eller ljus fick bergfinkarna att öka volymen på sitt tjatter och många fåglar lyfte med vingljud av stormvindar.

Making any general statement on the accuracy of the different methods, and how they compare, is difficult since it depends on how the individual parameters are estimated. However, as I discuss various studies in subsequent sections, I will argue that that the use of flock volume and density should be avoided. In many works, width and height in method $\mathrm{C}$ seem to be set somewhat arbitrarily (and keep in mind that the difficulty of estimating distances by eye is widely recognised). In addition, there is no agreement on the average bird density in streams of Bramblings. In fact, it should be expected that this varies significantly from roost to roost, and even from day to day at a single roost (depending on, e.g., weather and foraging patterns). This means that method B is most likely far more error-prone than other methods. If width and height is estimated from photos (from size variations of birds in the picture, see Figure 8 for an example), method B can become more accurate, albeit at the same time essentially turning into a complicated version of method A.

In the future, new approaches may help to reach better number estimates. Airborne thermography was proposed already 40 years ago (Hémery \& Pascaud 1981), and with the increasing availability of infrared and thermal cameras (or even regular video cameras) 
roosts will likely be studied in more detail in the future. Approaches based on quantitative monitoring of sound or droppings are also conceivable. In addition, increasing availability of counting software, for example based on machine learning, will simplify counting based on films or photographs.

\section{REPORTS WITH DETAILS ON NUMBER AND ROOST AREA}

I summarise and briefly comment on reports that provide details on number and roost areas in Table 1. The spread in reported numbers and roost areas is significant (visualised in Figure 9), and both number estimation and roost area definitions seem to vary greatly. When disregarding works that seemingly have a too wide definition of roost area, the roost density (birds per area) varies from some 0.3 million/ ha to 7.5 million/ha. This corresponds to a factor of 25 between the lowest and highest estimates of birds per roost area, a spread that motivated further scrutiny. It turns out to be very difficult to condense this material into any simple rule of thumb, but based on careful reading of the material, I come to the conclusion that the number of birds per roost area is on the order of one million/ha (see Figure 9). There are a few works in which much higher roost densities are reported, but a closer look reveals that the underlying numbers lack adequate support (no details, or unclarities, on how flock dimensions and/or intensities were inferred, as I will describe in subsequent sections). There are also some reports of much lower densities (Fulín \& Olekšák 2017, Kestenholz \& Schaffner 1993), but this is likely related to overestimation of the actual roost area used during the night (see comments in Table 1). In the end, however, it should be expected that the density per roost area will vary significantly with, for example, age, size, and density of

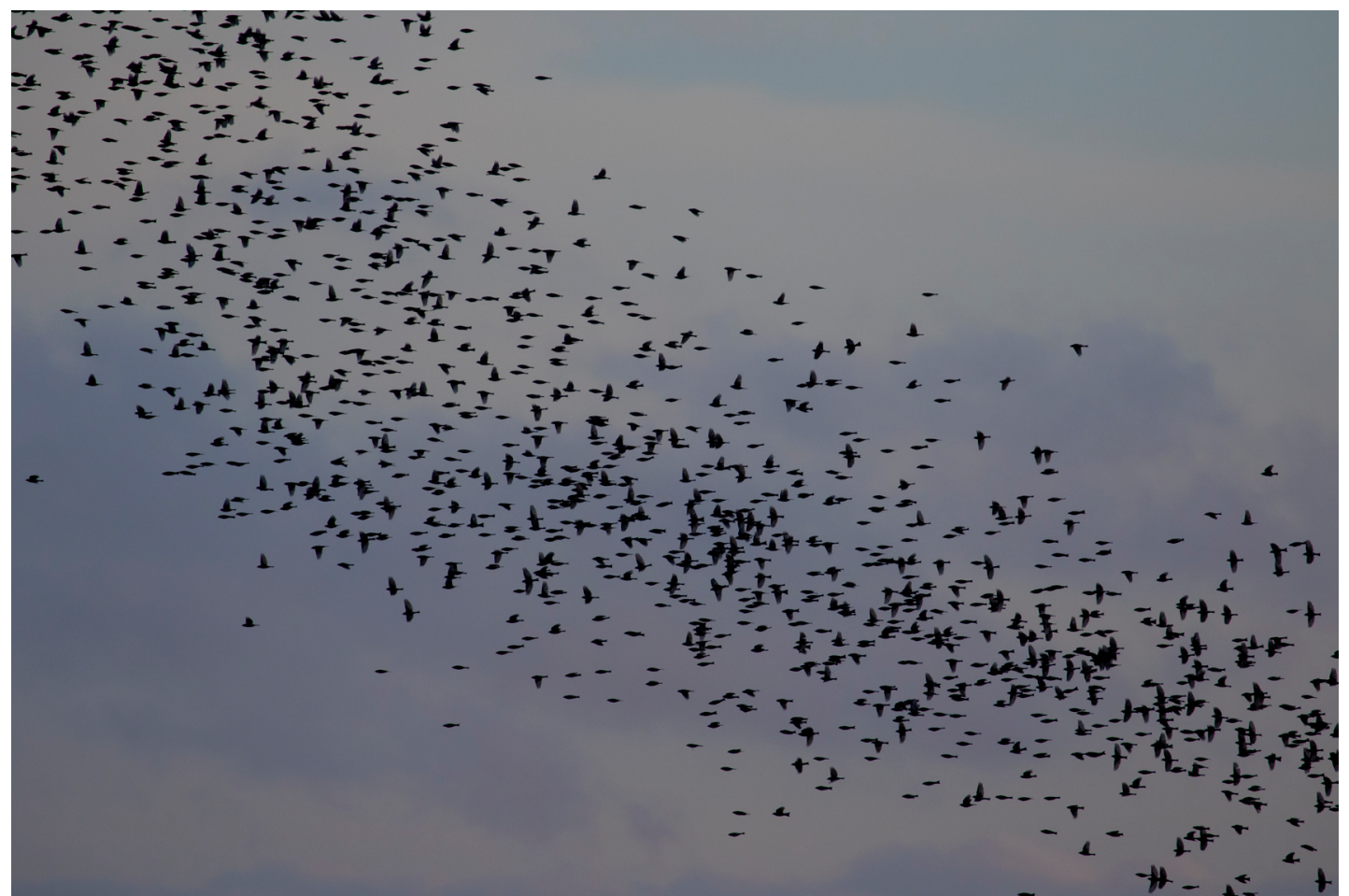

FIGURE 8. Flock density analysis example. The photo, which was taken at the roost site on 14 January 2020, contains around 1,217 Bramblings Fringilla montifringilla (manually marked) at a distance of 182-214 $\mathrm{m}$. The calculations (see text) arrive at a bird density $\rho$ of 1.1-3.0 $\mathrm{m}^{-3}$. The visible flock length is around $11 \mathrm{~m}$ and, assuming a flight speed of $15 \mathrm{~m} / \mathrm{s}$, the stream intensity is around 1,600 birds per second. - Exempelbild för analys av flocktäthet. Fotot, som togs vid sovplatsen 14 januari 2020, innehåller ca 1217 bergfinkar Fringilla montifringilla (räknade för hand) på ett avstånd om 182-214 m. Beräkningarna (som redogörs för i huvudtexten) leder till en flocktäthet $\rho$ om 1.1-3.0 m³. Den synliga flocklängden är ca $11 \mathrm{~m}$, och antas en flyghastighet om $15 \mathrm{~m} / \mathrm{s}$ blir det resulterande flödet ca 1600 fåglar per sekund. 


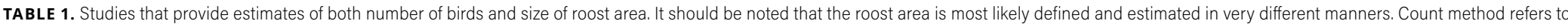
methods A (stream intensity and time), B (flock volume and density), and C (number of trees and birds per tree), described further in the main text.

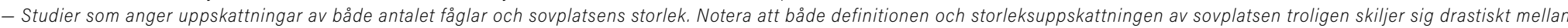
studierna. Räkningsmetod hänvisar till huvudtexten och baseras i korthet på (A) flöde och tid, (B) flockvolym och täthet och (C) antal träd och antal fåglar per träd.

\begin{tabular}{|c|c|c|c|c|c|c|}
\hline $\begin{array}{l}\text { Year } \\
\text { Ar }\end{array}$ & $\begin{array}{l}\text { Location } \\
\text { Plats }\end{array}$ & $\begin{array}{l}\text { Roost area } \\
\text { Sovplatsareal }\end{array}$ & $\begin{array}{l}\text { Method } \\
\text { Metod }\end{array}$ & Number estimate and remarks & Uppskattat antal samt kommentarer & $\begin{array}{l}\text { Reference } \\
\text { Referens }\end{array}$ \\
\hline $\begin{array}{l}1915- \\
1916\end{array}$ & $\begin{array}{l}\text { Kågeröd, } \\
\text { Skåne, } \\
\text { Sweden } \\
\text { Sverige }\end{array}$ & $0.5-1$ ha & $?$ & $\begin{array}{l}5.4 \text { million, based on } 45-\text { min fly-in at a presumed inten- } \\
\text { sity of } 2,000 \text { birds / s (without further motivation). The } \\
\text { roost area is stated to be "något tunnland" in Swedish, } \\
\text { i.e. around one barrel of land ( } 0.5 \text { ha). }\end{array}$ & $\begin{array}{l}\text { 5,4 miljoner, baserat på } 45 \text { min inflygning med en } \\
\text { intensitet om } 2000 \text { făglar per sekund (utan vidare } \\
\text { motivering). Sovplatsarealen är angiven som "något } \\
\text { tunnland", dvs. 0,5 ha. }\end{array}$ & Granvik (1916) \\
\hline $\begin{array}{l}1946- \\
1947\end{array}$ & $\begin{array}{l}\text { Porrentruy, } \\
\text { Ajoie, } \\
\text { Switzerland } \\
\text { Schweiz }\end{array}$ & $10.5 \mathrm{ha}^{\star \dagger}$ & B & $\begin{array}{l}\text { 11-16 million, based on } 45-\mathrm{min} \text { morning lift-off in a } \\
\text { stream } 100 \mathrm{~m} \text { wide and } 5-7 \mathrm{~m} \text { high, a ground speed } \\
\text { of } 60 \mathrm{~km} / \mathrm{h} \text { and } 0.512 \text { birds } / \mathrm{m}^{3} \text { (corresponding to an } \\
\text { average intensity of } 4,000-6,000 \text { birds / s). }\end{array}$ & $\begin{array}{l}\text { 11-16 miljoner baserat på } 45 \text { min morgonlyft i en } \\
100 \mathrm{~m} \text { bred och } 5-7 \mathrm{~m} \text { hög ström med en flyghastighet } \\
\text { om } 60 \mathrm{~km} / \mathrm{h} \text { och en täthet på 0,512 fåglar } / \mathrm{m}^{3} \text { (mots- } \\
\text { varande en intensitet av } 4000-6000 \text { fåglar } / \mathrm{s} \text { ). }\end{array}$ & Guéniat (1948) \\
\hline $\begin{array}{l}1950- \\
1951\end{array}$ & $\begin{array}{l}\text { Hünibach, } \\
\text { Thun, } \\
\text { Switzerland } \\
\text { Schweiz }\end{array}$ & $\begin{array}{l}12.6 \text { ha* } \\
(2 \times 6.8 \text { ha })\end{array}$ & B & $\begin{array}{l}72 \text { million, based on } 45 \text {-min fly-in in a } 200 \mathrm{~m} \text { wide and } \\
4 \mathrm{~m} \text { high stream, a ground speed of } 60 \mathrm{~km} / \mathrm{h} \text { and } 1 \\
\text { bird } / \mathrm{m}^{3} \text {, thereafter doubled since there were two simi- } \\
\text { lar adjacent roost areas (corresponding to an intensity of } \\
13,300 \mathrm{~s}^{-1} \text { per roost). Other assessors propose far lower } \\
\text { numbers (Jenni \& Neuschulz 1985). }\end{array}$ & $\begin{array}{l}72 \text { miljoner, baserat på } 45 \text { min inflygning i en } 200 \mathrm{~m} \\
\text { bred och } 4 \text { m hög ström, flyghastighet av } 60 \mathrm{~km} / \mathrm{h} \text { och } \\
1 \text { fågel/ } \mathrm{m}^{3} \text {, därefter dubblat eftersom två jämnstora } \\
\text { intilliggande sovplatser fanns (motsvarar en intensitet } \\
\text { av } 13300 \text { fåglar /s per sovplats). }\end{array}$ & $\begin{array}{l}\text { Mühlethaler } \\
\text { (1952), } \\
\text { Schifferli (1953) }\end{array}$ \\
\hline $\begin{array}{l}1964- \\
1965\end{array}$ & $\begin{array}{l}\text { Pau, } \\
\text { Pyrénées- } \\
\text { Atlantiques, } \\
\text { France } \\
\text { Frankrike }\end{array}$ & $10-13$ ha & $?$ & 15 million stated without further details. & 15 miljoner, angivet utan några vidare detaljer. & $\begin{array}{l}\text { Alberny et al. } \\
(1965)\end{array}$ \\
\hline $\begin{array}{l}1977- \\
1978\end{array}$ & $\begin{array}{l}\text { Etobon, } \\
\text { Haute-Saône, } \\
\text { France } \\
\text { Frankrike }\end{array}$ & 16.1 ha & $B(A)$ & $\begin{array}{l}12 \text { or } 121 \text { million, based on two different calculations. } \\
\text { The lower number is based on an analysis of a photo } \\
\text { with } 5,565 \text { birds over a width of } 32 \mathrm{~m} \text { in combination } \\
\text { with a } 70 \text {-min fly-in at } 60 \mathrm{~km} / \mathrm{h} \text { (i.e. } 2,900 \text { birds/s). The } \\
\text { larger (unreasonable) number, which is the one stated in } \\
\text { the conclusion, is reached after arguing that the stream } \\
\text { was } 250 \mathrm{~m} \text { wide and } 50 \mathrm{~m} \text { high and contained } 0.138 \\
\text { birds } / \mathrm{m}^{3} \text { (i.e. } 29,000 \text { birds/s). }\end{array}$ & $\begin{array}{l}12 \text { eller } 121 \text { miljoner, baserat på två olika beräkningar. } \\
\text { Den lägre siffran baseras på analys av ett foto med } 5 \\
565 \text { fåglar över en bredd av } 32 \mathrm{~m} \text { i kombination med } \\
\text { en } 70 \text { min inflygning i } 60 \mathrm{~km} / \mathrm{h} \text { ( } 2900 \text { fåglar } / \mathrm{s}) \text {. Den } \\
\text { högre (orimliga) siffran, vilken anges som slutsats, nås } \\
\text { efter påstående om att strömmen var } 250 \mathrm{~m} \text { bred } \\
\text { och } 50 \mathrm{~m} \text { hög och innehöll 0,138 fåg/ar } / \mathrm{m}^{3} \text { (29000 } \\
\text { fåglar/s). }\end{array}$ & $\begin{array}{l}\text { Nardin \& Brauch- } \\
\text { le (1979) }\end{array}$ \\
\hline $\begin{array}{l}1990- \\
1991\end{array}$ & $\begin{array}{l}\text { Magden, } \\
\text { Switzerland } \\
\text { Schweiz }\end{array}$ & $\begin{array}{r}5 \mathrm{~km}^{2} \\
(500 \mathrm{ha})\end{array}$ & ? & $\begin{array}{l}\text { 2-3 million, stated without any further detail. Compared } \\
\text { to other roosts, the area appears to be unreasonably } \\
\text { large. }\end{array}$ & $\begin{array}{l}\text { 2-3 miljoner, angivet utan vidare detaljer. Jämfört med } \\
\text { andra sovplatser förefaller arealen orimligt stor. }\end{array}$ & $\begin{array}{l}\text { Kestenholz \& } \\
\text { Schaffner (1993) }\end{array}$ \\
\hline
\end{tabular}


TABLE 1 continued fortsatt

\begin{tabular}{|c|c|c|c|c|c|c|}
\hline $\begin{array}{l}\text { Year } \\
\text { Ar }\end{array}$ & $\begin{array}{l}\text { Location } \\
\text { Plats }\end{array}$ & $\begin{array}{l}\text { Roost area } \\
\text { Sovplatsareal }\end{array}$ & $\begin{array}{l}\text { Method } \\
\text { Metod }\end{array}$ & Number estimate and remarks & Uppskattat antal samt kommentarer & $\begin{array}{l}\text { Reference } \\
\text { Referens }\end{array}$ \\
\hline $\begin{array}{l}1992- \\
1993\end{array}$ & $\begin{array}{l}\text { Frick, } \\
\text { Switzerland } \\
\text { Schweiz }\end{array}$ & $\begin{array}{l}0.5 \mathrm{~km}^{2} \\
(50 \mathrm{ha})\end{array}$ & $?$ & $\begin{array}{l}\text { 2-3 million, stated without any further detail. Compared } \\
\text { to other roosts, the area appears to be unreasonably } \\
\text { large. }\end{array}$ & $\begin{array}{l}\text { 2-3 miljoner, angivet utan vidare detaljer. Jämfört med } \\
\text { andra sovplatser förefaller arealen orimligt stor. }\end{array}$ & $\begin{array}{l}\text { Kestenholz \& } \\
\text { Schaffner (1993) }\end{array}$ \\
\hline $\begin{array}{l}1992- \\
1993\end{array}$ & $\begin{array}{l}\text { Västersjön, } \\
\text { Skåne, } \\
\text { Sweden } \\
\text { Sverige }\end{array}$ & 7.5 ha & C & $\begin{array}{l}2 \text { million, stated as a minimum based on around 7,500 } \\
\text { trees and } 200-500 \text { birds per tree. A similar number was } \\
\text { reached in a fly-in count (Lithner 1995). Large numbers } \\
\text { of dead and dying birds at the site. }\end{array}$ & $\begin{array}{l}2 \text { miljoner, angett som ett minimum baserat på } 7500 \\
\text { träd och 200-500 fåglar per träd. En liknande antalssif- } \\
\text { fra nåddes vid räkning under inflygning (Lithner 1995). } \\
\text { Stora antal döda och döende fåglar fanns på platsen. }\end{array}$ & $\begin{array}{l}\text { Kjellén \& Lind- } \\
\text { ström (1993) }\end{array}$ \\
\hline $\begin{array}{l}2001- \\
2002\end{array}$ & $\begin{array}{l}\text { Fontenais, } \\
\text { Ajoie, } \\
\text { Switzerland } \\
\text { Schweiz }\end{array}$ & $10 \mathrm{ha}^{* \dagger}$ & $?$ & $\begin{array}{l}\text { 10-12 million. Not exactly clear how this span was } \\
\text { inferred. The estimation was based on a 32-min fly-in } \\
\text { of a stream estimated to be } 50 \mathrm{~m} \text { wide, } 15 \mathrm{~m} \text { high and } \\
\text { moving at } 60 \mathrm{~km} / \mathrm{h} \text {. An intensity of } 5,000 \text { birds } / \mathrm{s} \text { is } \\
\text { stated as a minimum. The given } 10-12 \text { million range } \\
\text { would correspond to a calculation based on the stream } \\
\text { estimate using } 0.4-0.5 \text { birds } / \mathrm{m}^{3} \text {. Area description and } \\
\text { map not in perfect agreement. }\end{array}$ & $\begin{array}{l}\text { 10-12 miljoner. Inte helt klart hur detta spann nåddes. } \\
\text { Skattningen baseras på } 32 \text { min inflygning i } 60 \mathrm{~km} / \mathrm{h} \\
\text { i en ström som uppskattades vara } 50 \mathrm{~m} \text { bred och } \\
15 \mathrm{~m} \text { hög. En intensitet av } 5000 \text { fåglar } / \mathrm{s} \text { anges som } \\
\text { minimum. Spannet } 10-12 \text { motsvarar ett antagande om } \\
0.4-0.5 \text { fåg/ar } / \mathrm{m}^{3} \text {. Viss diskrepans mellan arealbes- } \\
\text { krivning och karta. }\end{array}$ & Chalverat (2003) \\
\hline $\begin{array}{l}2008- \\
2009\end{array}$ & $\begin{array}{l}\text { Gelnica, } \\
\text { Slovakia } \\
\text { Slovakien }\end{array}$ & 25-30 ha & A & $\begin{array}{l}\text { 1.5-3.5 million, based on photo analysis. Roost area not } \\
\text { given in the article but communicated by M. Fulín. Com- } \\
\text { pared to other roosts, this estimate seems unreasonably } \\
\text { large (but Fulín mentioned that the area includes several } \\
\text { hectares of lake). }\end{array}$ & $\begin{array}{l}\text { 1,5-3,5 miljoner, baserat på analys av fotografier. Areal } \\
\text { anges inte i artikel men har kommunicerats brevledes. } \\
\text { Jämfört med andra sovplatser förefaller arealen } \\
\text { orimligt stor (men sades inkludera flera hektar sjö). }\end{array}$ & $\begin{array}{l}\text { Fulín \& Olekšák } \\
\text { (2017), M. Fulín } \\
\text { (pers. comm.) }\end{array}$ \\
\hline $\begin{array}{l}2008- \\
2009\end{array}$ & $\begin{array}{l}\text { Lödersdorf, } \\
\text { Austria } \\
\text { Österrike }\end{array}$ & 2.26 ha & A & $\begin{array}{l}\text { 4-5 million, based on photo analysis on several locations } \\
\text { around the roost. }\end{array}$ & $\begin{array}{l}\text { 4-5 miljoner, baserat på analys av fotografier tagna på } \\
\text { flera positioner runt sovplatsen. }\end{array}$ & Khil et al. (2011) \\
\hline $\begin{array}{l}2010- \\
2011\end{array}$ & $\begin{array}{l}\text { Barazar, } \\
\text { Basque, } \\
\text { Spain } \\
\text { Spanien }\end{array}$ & $3-5$ ha & $?$ & $\begin{array}{l}0.9 \text { million. Droppings very unevenly distributed in the } \\
50 \text {-ha area mentioned in the article. Actual roost much } \\
\text { smaller, and limited to patches of Lawson cypress } \\
\text { Chamaecyparis lawsoniana, but not discussed explicitly. } \\
\text { J. Zabala guesses that } 3-5 \text { ha may have been used for } \\
\text { actual roosting and that the number may have been in } \\
\text { the span } 0.7-12 \text { million birds. }\end{array}$ & $\begin{array}{l}\text { 0,9 miljoner. Spillning ojämnt fördelad över den } \\
\text { angivna } 50 \text { ha stora sovplatsarealen. Faktiskt sovplats } \\
\text { betydligt mindre och lokaliserad till fläckar med } \\
\text { ädelcypress Chamaecyparis lawsoniana (nämns ej } \\
\text { i artikel). J. Zabala gissar att 3-5 ha användes som } \\
\text { sovplats och att antalet fäglar kan ha varit i spannet } \\
\text { 0,7-12 miljoner. }\end{array}$ & $\begin{array}{l}\text { Zabala et al. } \\
\text { (2012), J. Zabala } \\
\text { (pers. comm.) }\end{array}$ \\
\hline $\begin{array}{l}2016- \\
2017\end{array}$ & $\begin{array}{l}\text { Klenovec, } \\
\text { Slovakia } \\
\text { Slovakien }\end{array}$ & 40 ha & A & $\begin{array}{l}0.5 \text { million, based on photo analysis. Compared to other } \\
\text { roost, the area seems unreasonably large. }\end{array}$ & $\begin{array}{l}\text { 0,5 miljoner, baserat på fotoanalys. Jämfört med andra } \\
\text { sovplatser förefaller arealen orimligt stor. }\end{array}$ & $\begin{array}{l}\text { Fulín \& Olekšák } \\
\text { (2017) }\end{array}$ \\
\hline
\end{tabular}


TABLE 1 continued fortsatt

\begin{tabular}{|c|c|c|c|c|c|c|}
\hline $\begin{array}{l}\text { Year } \\
\text { Ar }\end{array}$ & $\begin{array}{l}\text { Location } \\
\text { Plats }\end{array}$ & $\begin{array}{l}\text { Roost area } \\
\text { Sovplatsareal }\end{array}$ & $\begin{array}{l}\text { Method } \\
\text { Metod }\end{array}$ & Number estimate and remarks & Uppskattat antal samt kommentarer & $\begin{array}{l}\text { Reference } \\
\text { Referens }\end{array}$ \\
\hline $\begin{array}{l}2018- \\
2019\end{array}$ & $\begin{array}{l}\text { Velika, } \\
\text { Preska, } \\
\text { Slovakia } \\
\text { Slovakien }\end{array}$ & 5 ha & $A$ & $\begin{array}{l}5 \text { million, based on photo analysis. Series of photos were } \\
\text { taken during morning lift-offs (ground speed estimated } \\
\text { by measuring how long it took for birds to pass the cam- } \\
\text { era field of view, done by following individual birds and } \\
\text { marking start and stop times using a voice recording). T. } \\
\text { Mihelič states that the roost area may have been up to } \\
\text { around } 9 \text { ha. }\end{array}$ & $\begin{array}{l}5 \text { miljoner, baserat på fotoanalys. Serier av foton } \\
\text { analyserades och flyghastigheten uppskattades genom } \\
\text { att med hjälp av diktafon notera hur lång tid fåglar } \\
\text { behövde för att passera bildvinkeln). T. Mihelič anger } \\
\text { att sovplatsarealen kan ha varit upp till } 9 \text { ha. }\end{array}$ & $\begin{array}{l}\text { Tout (2019), } \\
\text { T. Mihelič (pers. } \\
\text { comm.) }\end{array}$ \\
\hline $\begin{array}{l}2019- \\
2020\end{array}$ & $\begin{array}{l}\text { Kliplev, } \\
\text { Denmark } \\
\text { Danmark }\end{array}$ & 1.3 ha* & $?$ & $\begin{array}{l}0.2-1.2 \text { million. Various number estimates from several } \\
\text { observers, typically based on estimates of volume and } \\
\text { bird density of flocks flying over the roost area. The } \\
\text { roost area has been estimated to } 1.3 \text { ha (Hansen 2020) } \\
\text { and 2-2.5 ha (Martinek Langholz 2020). }\end{array}$ & $\begin{array}{l}\text { 0,2-1,2 miljoner. Olika siffror från olika observatörer, } \\
\text { ofta baserat på uppskattningar av volym och täthet hos } \\
\text { flockar flygande över sovplatsen. Areal har uppskattats } \\
\text { till } 1.3 \text { ha (Hansen 2020) och 2-2,5 ha (Martinek } \\
\text { Langholz 2020). }\end{array}$ & $\begin{array}{l}\text { Hansen (2020), } \\
\text { Martinek Lang- } \\
\text { holz (2020) }\end{array}$ \\
\hline $\begin{array}{l}2019- \\
2020\end{array}$ & $\begin{array}{l}\text { Lake } \\
\text { Rössjön, } \\
\text { Skåne, } \\
\text { Sweden } \\
\text { Sverige }\end{array}$ & $5.6 \mathrm{ha}^{* \dagger}$ & & $\begin{array}{l}4-10 \text { million based on photo analysis from a fly-in } \\
\text { around } 20 \mathrm{~km} \text { from the roost. }\end{array}$ & $\begin{array}{l}\text { 4-10 miljoner baserat på analys av foton från en } \\
\text { inflygning observerade } 20 \mathrm{~km} \text { från sovplatsen. }\end{array}$ & This study \\
\hline
\end{tabular}

* Studies include a roost map. Studierna inkluderar en karta över sovplatsen.

${ }^{\dagger}$ The work explicitly states that the roost area was demarcated based on excrement layers. Studien anger explicit att sovplatsens yta avgränsades med ledning av spillning på marken.

trees, temperature, local variation of microclimate, total suitable area in relation to the number of Bramblings accumulated during the winter, etc. As an example, the large Slovenian roost in 2018-2019 comprised large, older trees (T. Mihelič, pers. comm.), while the Swiss roost in 1946-1947 was situated in an area with young trees, most below $8 \mathrm{~m}$ in height (Guéniat 1948). It should not be expected that the bird roosts will have similar densities when the vegetation can differ that much.

\section{REGARDING THE ALLEGED 70-MILLION ROOST IN THUN 1950-1951}

The famous and frequently cited 72-million roost from Thun, Switzerland 19501951 (Mühlethaler 1952), often referred to as 70 million, deserves a closer look. The number comes from a doubling of an estimate of birds arriving to one of two adjacent roost areas separated by around $300 \mathrm{~m}$. The stream of birds was estimated to be $200 \mathrm{~m}$ wide and $4 \mathrm{~m}$ high, and the duration of the fly-in was 45 minutes. Assuming a ground speed of $60 \mathrm{~km} / \mathrm{h}$, the length of the stream was estimated to $45,000 \mathrm{~m}$. Mühlethaler (1952) argues that $1 \mathrm{bird} / \mathrm{m}^{3}$ is a reasonable lower limit for the bird density and thus reaches $200 \mathrm{~m} \times 4 \mathrm{~m} \times 45$, $000 \mathrm{~m} \times 1$ birds $/ \mathrm{m}^{3}=36 \mathrm{mil}-$ lion birds (for each of the two roost sections). This corresponds to an average intensity of 13,000 birds per second, per roost. Along with some 30 million birds in other parts of Switzerland this winter, this roughly corresponds to the complete European post-breeding population. Although this number estimate received some 
support from Schifferli (1953), it has been rejected by others. Lukas Jenni, most likely the ornithologist who has spent most time studying the winter habits of Bramblings in Europe, even argues that the estimate may be more than a factor of ten too high (Jenni 1984, Jenni \& Neuschulz 1985). The main objections are that the bird density is overestimated and that it is very difficult to accurately determine width and height of a bird stream. While Mühlethaler (1952) suggests that a flock density of $1 \mathrm{~m}^{-3}$ should be an underestimation, Jenni \& Neuschulz (1985) argue that $0.04-0.1 \mathrm{~m}^{-3}$ is more reasonable, which would bring down the number from 72 million to 2.8-7 million. Jenni \& Neuschulz (1985) refer to stereo photography on Brambling flocks during autumn mi-

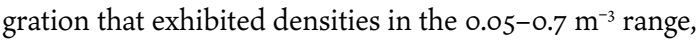
and that Nardin \& Brauchle (1979) in their analysis of photographs estimated the density to around $0.1 \mathrm{~m}^{-3}$ in dense regions, and $0.04 \mathrm{~m}^{-3}$ on average.

However, I find the analysis of Nardin \& Brauchle (1979) rather confusing and suspect that the range
0.04-0.1 $\mathrm{m}^{-3}$ underestimates how dense Bramblings can fly at a roost. Jenni \& Neuschulz (1985) refer to measurements of density during autumn migration that yielded up to $0.7 \mathrm{~m}^{-3}$, and my personal experience is that Bramblings sometimes fly in denser formation in connection to the winter roost than what they do, for example, during autumn migration at Falsterbo (Sweden). To assess this further, I evaluated two photos from occasions at the Swedish 2019-2020 roost, where I found the Bramblings to fly in particularly dense formation. In these photos, the width of the stream was estimated from the variation in size (in pixels) of the photographed birds. The two photos were rather different in character (one photo of a smaller and well-defined flock, and one capturing part of a longer stream). In both cases, the resulting density estimate was $1-3 \mathrm{~m}^{-3}$. As an example, here follow the details of this analysis for one of the photos (Figure 8): The photo contains around 1,217 Bramblings (manually marked) and is taken with a $3.23^{\circ}$ field-of-view lens (Canon

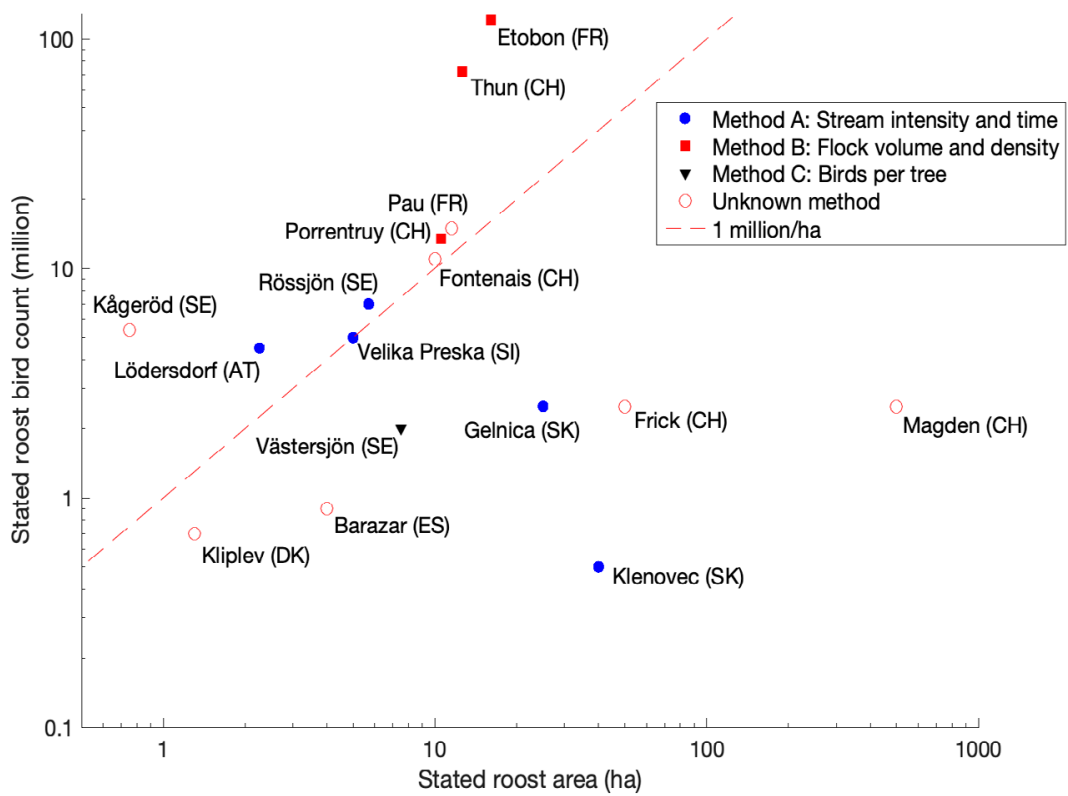

FIGURE 9. Scatterplot in logarithmic scale showing the variability in stated number of Bramblings Fringilla montifringilla and roost area size (Table 1). The four datapoints with roost areas exceeding 20 ha (Gelnica, Klenovec, Frick, and Magden) are, in my opinion, cases where the roost area has been overestimated (all detailed studies on large Brambling roosts indicate that they roost very densely, see Table 1 for details). The number estimates for the roosts in Kågeröd, Thun, and Etobon lack detailed justification and I argue that they result from overestimations. - Spridningsdiagram med logaritmerade skalor, som visar variationen i angivna antalet bergfinkar Fringilla montifringilla och sovplatsens storlek (tabell 1). De fyra datapunkter med sovplatser större än 20 ha (Gelnica, Klenovec, Frick och Magden) är, enligt min åsikt, fall där storleken överskattats (alla detaljerade studier av större sovplatser för bergfinkar indikerar att fåglarna övernattar mycket tätt, se tabell 1 för detaljer). Uppskattningarna av antal bergfinkar i Kågeröd, Thun och Etobon saknar detaljerade redogörelser och jag betraktar dem som överskattningar. 
EOS7D with EF10o-400 mm f/4.5-5.6L IS II USM at its maximum focal length). Bramblings are around $15 \mathrm{~cm}$ long and occupy in 68-80 pixels, which corresponds to a distance range of $182-214 \mathrm{~m}$. Since we have neglected length variations, this range should serve as an upper limit of the flock width (assuming a $10 \%$ size difference from the smallest to the largest bird, one could argue that the flock width could be as low as around $10-15 \mathrm{~m}$ ). The stream is around $3 \mathrm{~m}$ high, and the length captured by the photo is around $11.2 \mathrm{~m}$. A lower limit for the bird density $\rho$ is reached when using the upper width estimate: $\rho_{\min }=1,217$ / $(3 \times 32 \times 11.2) \approx 1.1 \mathrm{~m}^{-3}$. With size variation in mind, the density could be as high as $3 \mathrm{~m}^{-3}$. While this shows that Bramblings can fly much more densely than at $0.1 \mathrm{~m}^{-3}$, it should be noted that they often flew in much less dense formation than this. In fact, the photo (Figure 8) was taken when the Bramblings flew particularly densely at the roost site on 14 January 2020. Assuming that the birds fly at $15 \mathrm{~m} / \mathrm{s}$ (Alerstam et al. 2007), this stream corresponds to an intensity of around 1,600 birds per second.

It is, of course, purely coincidental that the density estimates were so similar for the two photos, but it still shows that Bramblings can fly much more densely than at $0.04-0.1 \mathrm{~m}^{-3}$. Schifferli (1953) made a similar exercise: he studied photos of a stream, taken from below, somewhat arbitrarily assumed a stream height of $4 \mathrm{~m}$, and counted 87 finches in $20 \mathrm{~m}^{2}$. This results in a density of $1.1 \mathrm{~m}^{-3}$. Based on experiences from the Swedish roost, however, I would still say that Bramblings not always fly in this dense flocks.

In general, I fully agree with Jenni \& Neuschulz (1985) that (i) number estimates via flock volume and density should be avoided, especially if these quantities are not carefully measured, and (ii) number estimates are much better done by estimating the intensity of birds passing an observer, preferably with the help of photographs.

So, how many birds could there have been in Thun? It is worth mentioning that there are other assessors than Jenni \& Neuschulz (1985), who have proposed lower numbers than Mühlethaler (1952). Egli (1951), for example, states that it was impossible to make any proper count but that 5 million should not be an overestimation. Moreover, according to Jenni \& Neuschultz (1985), a certain Frutiger reached the number 1-2 mil- lion after analysis of photos. That numbers disagree is one thing-they often seem to do in the context of large flocks-but the question is who made the least inaccurate estimate. It should be noted that also the lower numbers presented are rather poorly founded. There is, however, yet another aspect to consider: the roost area. Mühlethaler (1952) specified the area to cover 13.6 ha, and that it comprised trees of Norway spruce and European silver fir Abies alba at the age of 20-50 years. Compared to other roosts, many carefully studied, the resulting density of 5.3 million/ha appears surprisingly high. Although impossible to prove, I suspect that an overestimation has been caused by overestimation of both stream width and density. A stream that was $200 \mathrm{~m}$ wide and as dense as $1 \mathrm{~m}^{-3}$ continuously for 45 minutes sounds rather extreme (around 13,000 birds/s on average, for each roost).

\section{REGARDING THE CLAIM OF 120 MILLION}

As can be seen in Table 1, it is rather common with number estimates based on flock volume and density (method B). In fact, the 72 million in Thun is not the highest number reached in this manner. Nardin \& Brauchle (1979) concluded that the roost in Etobon 1977-1978 comprised 100-120 million Bramblings. Their analysis is somewhat difficult to follow, but in my opinion their argument for setting the flock width and height to $250 \mathrm{~m}$ and $50 \mathrm{~m}$, respectively, is not convincing. It is interesting to note that, along with this volume/density calculation (method B), they also present a photo-based intensity analysis along the lines of method $\mathrm{A}$, which resulted in a total number of 12 million. This seems more reasonable for a 16-ha roost, and it can be noted that Francois (1978) in his description on this roost mentions, without any justification however, the number 10 million. It can perhaps have been more birds than that, but I agree with Jenni \& Neuschultz (1985) that the range 100-120 million is unrealistic. This may be an example of how previous overestimations drive new overestimations. In fact, Nardin \& Brauchle (1979) explicitly state that they consider their analysis more restrained than Mühlethaler's (1952), arguing that if they would use his density of $1 \mathrm{bird} / \mathrm{m}^{3}$, their estimate would increase to 875 million. While they may have been more careful in terms of bird density assumptions, their values for the height of the stream, which they set to $50 \mathrm{~m}$, is less conservative. 
Again, in my opinion, this is an example of how difficult it is to set flock dimensions correctly.

\section{ANNUAL MASS CONCENTRATIONS IN CORN DISTRICTS IN FRANCE 1960-1980}

In previous sections I have argued that the largest published values for Brambling roosts should be regarded as overestimations. Clearly, it is not easy to answer the question of how many birds that the largest Bramblings roosts have contained. The largest number mentioned in the review by Jenni (1987) is 20 million at a roost in Pau, Pyrénées-Atlantiques in France. The roost in Pau is not just another large roost-it represents fascinating Brambling history. Corn production increased in France during the twentieth century and Bramblings adapted to this new and abundant source of food. The roost in Pau was likely established in the early 1960 s and was occupied annually for several years (Alberny 1965). This is an interesting contrast to other very large roosts, which are formed during beech mast years and therefore used in single years (never several consecutive years). This interesting adaptation to changes in human farming was studied by Hémery \& Le Toquin (1975a, 1976), focussing on the energy needs of Bramblings and the supply offered by the losses in corn farming. Changes in corn farming, specifically early burial of stubble, around 1980 deprived the Bramblings of this abundant food resource (Dubois et al. 2008).

Regarding the specific value of 20 million, the most common source is an study on the energy expenditure of Bramblings by Hémery \& Le Toquin (1975a). For example, the reference work "Nouvel inventaire des oiseaux de France" by Dubois et al. (2008) also refers to this work when stating 20 million as the peak of the roost numbers in Pau ${ }^{1}$. Indeed, the study by Hémery \& Le Toquin (1975a) contains a data point in a scatterplot

1 Note that the reference given by Dubois et al. (2008) is incorrect: the cited article is titled "Déterminisme énergétique des concentrations de Pinsons du Nord ..", not "Déterminisme des concentrations de Pinsons du Nord.... The missing word énergétique constitutes an unfortunate typo, as it indicates that the focus is on determining concentration rather than energy expenditure. The typo may simply come from the winter atlas of France, as this work contains the very same typo (Hémery 1991). that corresponds to a roost number of 20 million. The value is, however, not commented further. According to Hémery \& Le Toquin (1976), the number 20 million refers to the number in December 1967, but I have not found any work in which the number estimate is elaborated. Sadly, the ornithologist and Brambling enthusiast Georges Hémery passed away in 2013 (Yésou et al. 2014) and could not give his view on these numbers. His colleague Alain Le Toquin believes that the value 20 million comes from Jean-Claude Alberny (A. Le Toquin pers. comm.). However, Jean-Claude Alberny (pers. comm.) does not recall any other number than 15 million, which he published in 1965 in his intriguing article describing the roost in Pau (Alberny 1965). The roost, in 1965 covering around 10-13 ha, was shared with European Starlings. While most roosts have been located in conifers such as Norway spruce, European silver fir, or Lawson cypress Chamaecyparis lawsoniana, birds here perched in Holly Ilex aquifolium, an evergreen, and stunted oaks Quercus sp. with retained dead (marcescent) leaves. The Bramblings were popular among hunters (not only in Pau) and served as food, and ringing revealed that many birds were injured:

\section{Le baguage a appris également limportant} pourcentage d'oiseaux blessés, près de $5 \%$ en janvier, chiffre diminuant par la suite. En effet les chasseurs apprécient cette espèce, aussi bien dans les Landes, le Gers et les Basses-Pyrénées où lon peut trouver des brochettes entières de ces «ortolans».

The quotation above translates into that ringing activities showed that $5 \%$ of the birds were injured in January, with a decrease in the fraction of injured birds thereafter, and that the hunters indeed appreciated the species and that skewers of this "ortolan" was served in several regions (a reference to the more well-known eating of Ortolan Bunting Emberiza hortulana).

Alberny (1965) also reported that some birds suffered from some kind of disease. Regarding the number of birds, Alberny suggests 15 million (Table 1). This is, however, a very rough estimate as birds came from all directions and proper counting seemed impossible to Alberny. Believing it to be an underestimation, Alberny writes:

Une évaluation parait impossible, les oiseaux arrivant de tous côtés à la fois. De plus la configuration du 
relief ne permet pas de voir le dortoir en entier. Les

Pinsons sont de très loin plus nombreux que les

Etourneaux. On peut affirmer sans crainte qu'il y en a au moins 15 MILLIONS ... Probablement plus ...

The essence of the text in this quotation is that counting felt impossible with birds arriving from all directions and where no observation spot allowed an overview of the whole roost (similar to conditions at the roost in Sweden 2019-2020), but that the Bramblings were far more numerous that the European Starlings and "safely" could be said to be at least 15 million. Unfortunately, there is no comment on how the estimate 15 million was reached.

It seems unlikely that Hémery studied the numbers in Pau as early as 1967. In an ambitious article from 1981, Hémery \& Pascaud elaborate on the difficulties of counting large numbers of birds and explore whether infrared thermography can be of assistance. In this work they also argued that proper counting at a roost requires multiple competent observers and that uncertainties nonetheless may be as high as $50 \%$ when dealing with gatherings of birds on the order of ten million. Results of two visual counts made in Pau in February 1979 are also presented: 2.3 million $\pm 25 \%$ on 5 February and later, when most birds had abandoned the roost, $450,000 \pm 33 \%$ on 14 February. The work does not contain any comparison with earlier numbers from Pau, nor details on how and by whom the counting was conducted in 1967, when 20 million was reported.

To conclude, it is difficult to confirm that there was as much as 20 million in a single roost in Pau. Given its large area (9-13 ha), the roost in Pau is without doubt one of the largest ever registered. Since a few roosts have been of similar size (Table 1), which one that held the highest number of Bramblings remains unknown.

\section{THE CLASSIC 1915-1916 ROOST IN SWEDEN}

Another interesting example is the internationally renowned winter roost in Kågeröd, Sweden, 1915-1916, studied in detail by Hugo Granvik (Granvik 1916a, Granvik 1916b, Nilsson 1983). In an otherwise detailed and careful study of a Brambling roost, the number 5.4 million given by Granvik lacks detailed justification. Granvik reaches 5.4 million by assuming that 2,000 birds per second arrived at the roost during the observed 45 -minute fly-in duration. The number in itself is not sensational, given what we know today, but as the roost area appears to have been rather small the number appears surprisingly high. Granvik specifies that roost area to "något tunnland" in Swedish, literally meaning around one barrel of land, i.e. 0.5 ha. That the roost area was rather small is also supported by sketches made by Nilsson (1983). It cannot, of course, be ruled out that the accumulation of Bramblings at this site, as the winter progressed, made this roost extraordinarily dense in relation to the available area. In fact, Granvik (1916a) writes that the Bramblings utilized birch trees at the border of the coniferous roost area. It is, however, not clear whether it was confirmed that these trees were populated also in the middle of the night. In the 2019-2020 roost in Sweden, movements from European beech trees into the actual roost was noted also after dusk.

\section{COUNTING TREES AND BIRDS PER TREE}

The study by Kjellén \& Lindström (1993) is, to the best of my knowledge, the only previous work that has conducted number estimation by estimating the number of trees and birds per tree (method C). The work concerns a roost in Sweden located in January 1993, comprising approximately 7.5 ha $(500 \mathrm{~m}$ by $150 \mathrm{~m})$ of plantations of Norway spruce of different ages and heights between 10 and $20 \mathrm{~m}$. Furthermore, it was estimated that there was on average one tree per $10 \mathrm{~m}^{2}$, resulting in a total tree count on 7,500. The authors estimated that at least 200 birds sat in each tree, and perhaps 500 in the larger ones, and conclude that the total number of Bramblings at the very least should be 2 million. A fly-in count (method B, but without photos) by Lithner (1995) also estimated the number of birds to at least 2 million. Since the stated roost area is rather large, the number may appear somewhat low. It is, however, worth noting that this particular roost seems to have suffered from some kind of deadly disease, as large numbers of dead birds were found within the roost area (Kjellén \& Lindström 1993).

As described earlier, observations at the Swedish 2019-2020 roost suggest that a single tree can host on the order of 1,000 finches. A similar number was suggested for larger trees in the well-studied roost in Switzerland 1916-1947 (Guéniat 1948). More studies on how many birds that roost per tree would be enlightening. 


\section{HIGH NUMBERS FROM NOWHERE}

I read around 100 texts on Bramblings as a part of this review and on a few occasions, I came across references to very high numbers that I could not track: the cited articles did not, as far as I can see, contain the attributed information. Unless other researchers have better luck in finding support in original sources, these numbers should not be cited. To facilitate future work on the topic, I have decided to explicitly mention these oddities in the vast literature on Brambling mass concentrations.

The perhaps most important case is a claim in the standard reference "Finches" by Newton (1972). Referring to Guéniat (1948) and Sutter (1948), Newton writes that there was a roost of 50 million Bramblings in Switzerland during the 1946-1947 winter. None of these articles contain such a number (perhaps a reference in Guéniat (1948) to Granvik's roost as comprising $5^{1 / 2}$ million was misinterpreted as $51-52$ million and rounded to 50 million?). Referring to Newton's text, this number is unfortunately cited in other important works. Another large number that lacks support is the 61 million that Møller \& Laursen (2019) cites, referring to Géroudet (1952). Finally, it should be noted that Chalverat (2003) incorrectly refers to the PhD thesis of Jenni (1984) when stating that the roost in Röserental 1977-1978 comprised 28 million birds. Instead, Jenni's thesis (p. 40-41) argues that the roost contained around 6 million birds (the range 2-9 million is also given). This estimation has also been published in journals (Jenni \& Neuschulz 1985, Jenni 1991).

\section{Discussion and conclusions}

The literature review presented in this work suggests that there is support for Brambling roosts involving up to around 15 million Bramblings. In terms of areal density of birds, a roost may hold on the order of one million birds/ha. As large variations in roost density can be expected, this should be seen as an utterly rough estimate in need of further verification. As a comparison, the Passenger Pigeon with its tenfold mass has been estimated to roost in densities of around 100,000 birds / ha (Ellsworth \& McComb 2003) and the Redbilled Quelea has been claimed to roost at densities of 2.5 million/ha (Manikowski 1988). Claims of higher numbers, or densities, such as the 70 million Bramblings from Switzerland 1951-1952, is based on questionable methods and does not fit well with the overall picture that emerges from the collection of reports on mass concentrations of Bramblings that has built up throughout the years. Unfortunately, despite that the number 70 million has been previously rejected (Jenni \& Neuschultz 1985), it keeps being cited without reservations in new works on mass appearances of birds. A main reason for this could be that it is presented, without reservations or discussions of uncertainties, in important reference works like "Finches" (Newton 1972) and "Bird Migration" (Alerstam 1993). (However, in later works, such as "Population Limitation in Birds", Newton (1998) adheres to Jenni's more restrictive view that values above 20 million lack proper support.)

Given the difficulty of counting large numbers of birds, reports of very large numbers should always be used and cited with great care, regardless of whether they concern Bramblings, European Starlings, North American blackbirds, Red-billed Queleas, or Passenger Pigeons. The ecological and economic significance of large flocks of birds motivates further studies. Clearly, much can be done to improve our knowledge of flock sizes of our most abundant birds. This includes Bramblings, despite all the efforts made so far. For example, there is no publication with a solid analysis and presentation of uncertainties in the number estimation conducted. In addition, roost areas are often not well investigated (map with demarcations missing). It would also be very valuable to see more work on accurate estimation of flock and roost sizes. From a critical point of view, millions should only be interpreted as many unless carefully described and justified. While Hémery \& Pascaud (1981) argued that, even with multiple competent observers, uncertainties may be $50 \%$ when numbers are in the ten-million range, the discussion about the 70-million and 120-million numbers (Mühlethaler 1952, Nardin \& Brauchle 1979, Jenni \& Neuschultz 1985) indicates that uncertainties can even be a factor of ten, depending on count method. Since a factor of ten difference in crop damage or population size matters, the topic of how mass concentrations of birds are counted and accounted for deserves further attention. 


\section{ROOST CHARACTERIZATION: A SHORT CHECKLIST}

- Counting. Try to monitor morning lift or evening fly-in from a spot with good overview. Make careful notes on timing (start and end of movements) and estimate the intensity of bird streams, preferably by taking systematic series of photographs. Avoid estimating numbers from flock volumes (width, height and length) and bird densities (birds per $\mathrm{m}^{3}$ ).

- Roost area. Determine roost boundaries via studies of excrement layers. Although zones around the roost, where birds gather before flying in, will show a lot of droppings, the actual roost area will be completely covered in excrements. Use the demarcation to estimate the roost area carefully, using a map tool (e.g. Google Maps).

- Document trees. Document trees in the roost (species, age, height, and distance between trees) and try to estimate the total number of trees.

- Birds per tree. Try to estimate the number of birds per tree, preferably during night using thermal cameras.

- Roosting in bare trees. If there are indications that birds sleep also in non-coniferous trees (e.g. in European beech or other deciduous trees), confirm this with, e.g., a thermal (infrared) camera in the middle of the night. The Bramblings move also after dusk, and evidence of roosting in, for example, peripheral deciduous trees would be interesting (cf. Granvik 1916a).

\section{Acknowledgements}

First of all, I would like to thank Hanna, Siri, and Vera for letting our family include also Bramblings for quite some months. There are also many who have contributed more directly to the work, for example by engaging in interesting discussions, supplying complementary information, assisting in my hunt for obscure references, lending me equipment, or reviewing and providing feedback on the manuscript. In particular, I would like to acknowledge the help from Thomas Alerstam, Johnny Jönsson, Nils Kjellén, Åke Lindström, Cecilia Nilsson, Lars Rippe, Sven G. Nilsson, and Roine Strandberg (Lund University, Sweden), Sara Agrup, Roland \& Jean-Claude Alberny, Janne Dahlén (Ecogain, Sweden), Igor Drobyshev and Rolf Övergaard (SLU, Sweden), Miro Fulín, Mats Hellmark (Sveriges Natur),
Nicole Hémery, Alain Le Touqin, Lukas Jenni, and Hans Schmidt (Schweizerische Vogelwarte, Switzerland), Tomaž Mihelič (BirdLife Slovenia), Yves Muller (LPO, France), Karin Persson (Falsterbo Bird Observatory, Sweden), Jean-Marc Pons and Jean-Pierre Siblet (Muséum national d'Histoire naturelle, France), Fritz Rosenörn (Rössjöholms gods, Sweden), Sissel Sjöberg (University of Copenhagen, Denmark), my brother Stefan Svensson, Jean-Marc Thiollay, Raffael Winkler (Naturhistorisches Museum Basel, Switzerland), Hasti Yavari (Axis Communications, Sweden), Pierre Yésou, Jabi Zabala, and one anonymous reviewer.

\section{References}

Alberny J, Gac JTL \& Venant H. 1965. Quelques observations sur un dortoir de Pinsons du Nord. Oiseaux de France 44: 18-25.

Alerstam T. 1990. Bird migration. Cambridge University Press, Cambridge.

Alerstam T, Rosén M, Bäckman J, Ericson PGP \& Hellgren O. 2007. Flight speeds among bird species: allometric and phylogenetic effects. PLoS Biology 5: e197. https://doi.org/10.1371/journal. pbio.0050197

Arizaga J, Zuberogoitia I, Zabala J, Crespo A, Iraeta A \& Belamendia G. 2012. Seasonal patterns of age and sex ratios, morphology and body mass of Bramblings Fringilla montifringilla at a large winter roost in southern Europe. Ringing \& Migration 27: 1-6. https://doi. org/10.1080/03078698.2012.686707

Beauchamp G. 1999. The evolution of communal roosting in birds: origin and secondary losses. Behavioral Ecology 10: 675-687. https://doi.org/10.1093/beheco/10.6.67

Bird Ringing Centre, Swedish Museum of Natural History. 2020. Ring recovery database. Retrieved from https://birdrecoveries.nrm.se.

Browne SJ \& Mead CJ. 2003. Age and sex composition, biometrics, site fidelity and origin of Brambling Fringilla montifringilla wintering in Norfolk, England. Ringing \& Migration 21: 145-153. https://doi.org/10.1080/03078698.2003.9674283

Bucher EH. 1992. The causes of extinction of the Passenger Pigeon. Pp 1-36 in Current Ornithology vol 9 (Power DM, ed). Springer, Boston, MA. https://doi.org/10.1007/978-1-4757-9921-7_1

Chalverat J. 2003. Le Pinson du Nord Fringilla montifringilla L.: un visiteur d'exception dans les forêts d'Ajoie durant l'hiver 2001-2002. Schweizerische Zeitschrift für Forstwesen 154: 449-445. https://doi.org/10.3188/szf.2003.0449

DOF-basen. 2020. Dansk Ornitologisk Forening's (DOF) database of bird observations. Retrieved from https://dofbasen.dk/.

Dougoud R. 2001. Pseudombrophila stercofringilla sp. nov. Mycologia helvetica 11: 145-152.

Drobyshev I, Niklasson M, Mazerolle MJ \& Bergeron Y. 2014. Reconstruction of a 253-year long mast record of european beech reveals its association with large scale temperature variability and no longterm trend in mast frequencies. Agricultural and Forest Meteorology 192: 9-17. https://doi.org/10.1016/j.agrformet.2014.02.010

Dubois P, Maréchal PL, Olioso G \& Yésou P. 20o8. Nouvel inventaire des oiseaux de France. Delachaux et Niestlé, Lonay.

Egli W. 1951. Beobachtungen am Schlafplatz eines Riesen-Bergfinkenzuges. Vögel der Heimat 21: 113-115. 
Ellsworth JW \& McComb BC. 2003. Potential effects of passenger pigeon flocks on the structure and composition of presettlement forests of eastern North America. Conservation Biology 17: 15481558. https://doi.org/10.1111/j.1523-1739.2003.00230.x

Feare CJ, Douville de Franssu P \& Peris SJ. 1992. The starling in Europe: multiple approaches to a problem species. Proceedings of the Vertebrate Pest Conference 15: 83-88. Available at https:// escholarship.org/uc/item/3n3895n3.

Francois J. 1978. Pinsons du Nord en Franche-Comté. Falco 13: 43-46.

Fulín M \& Olekšák M. 2017. K migrácii a zimnỳm nocoviskám piniek severskỳch (Fringilla montifringilla) na Slovensku. [On migration and winter roosting sites of Bramblings (Fringilla montifringilla) in Slovakia]. Tichodroma 29: 16-24. Available at http://www. tichodroma.sk/pdfs/29/Tichodroma_29_fulin.pdf.

Géroudet P. 1952. Notes sur les Pinsons du Nord en Suisse romande (hiver 1950-1951). Nos Oiseaux 21: 160-168.

Granvik H. 1916a. Bergfinkinvasionen i Skåne vintern 1915-1916. Fauna och Flora 11: 49-62.

Granvik H. 1916b. Zur Frage des zurückbleibens der Bergfinken in Schweden während des Winters 1915-1916. Journal für Ornithologie 64: 371-378. https://doi.org/10.1007/BFo2250486

Grodziński W \& Sawicka-Kapusta K. 197o. Energy values of tree-seeds eaten by small mammals. Oikos 21: 52-58. https://doi. org $/ 10.2307 / 3543838$

Guéniat E. 1948. Beobachtungen an einem Massenschlafplatz von Bergfinken in der Ajoie im Winter 1946/47. Ornithologischer Beobachter 45: 81-98.

Hafström M. 2012. Bergfinkar över Västersjön. YouTube. Retrieved from https://www.youtube.com/watch?v=xY6B61dRaVM.

Haikos A. 1950. Ein Einfall von Bergfinken nach zwei Berichten aus den 17. Jahrhundert. Ornithologischer Beobachter 47: 176-177.

Hancock P \& Weiersbye I. 2015. Birds of Botswana. Princeton University Press, Princeton, NJ. https://doi.org/10.1515/9781400874170

Hansen JM. 2020. Comment belonging to a report of the Bramblings in Kliplev from 2020-02-02. DOF-basen. Retrieved from https:// dofbasen.dk/popobs.php?obs=obs\&obsid $=23983555$ on 3 April 2020.

Hansen L. 1954. Birds killed at lights in Denmark 1886-1939. Videnskabelige Meddelelser fra den Naturhistoriske Forening $i$ København 116: 269-368.

Hémery G. 1991. Pinson du Nord. Pp 458-459 in Atlas des oiseaux de France en hiver (Yeatman-Berthelot D, ed). Société Ornithologique De France, Paris.

Hémery G \& Le Toquin A. 1975a. Déterminisme énergétique des concentrations de Pinsons du Nord (Fringilla montifringilla) en relation avec l'évolution de la culture du Maïs (Zea mais) en France de 1955 à 1973. Comptes Rendus de l'Académie des Sciences 281: 835-838.

Hémery G \& Le Toquin A. 1975b. Utilisation de la méthode des modèles pour l'étude des d'epenses énergétiques des populations de Pinsons du Nord (Fringilla montifringilla) en période internuptiale. Comptes Rendus de l'Académie des Sciences 280: 1153-1156.

Hémery G \& Le Toquin A. 1976. Dépenses énergétiques des populations hivernantes de Pinsons du Nord (Fringilla montifringilla) en relation avec leur milieu. La Terre et la Vie 30: 52-88. Available at https://bit.ly/3mdYrym.

Hémery G \& Pascaud P-N. 1981. Estimation de l'effectif de rassemblements d'oiseaux par thermographie infrarouge. Application á un dortoir de Pinsons du Nord (Fringilla montifringilla). L'Oiseau et la Revue Française d'Ornithologie 51: 1-16.

Holmgren AE. 1866. Handbok i zoologi for landtbrukare, skogshushållare, fiskeriidkare och jägare, II. delen: Skandinaviens foglar. PA Norstedt \& söner, Stockholm. https://doi.org/10.5962/bhl. title. 15364
Homan HJ, Johnson RJ, Thiele JR \& Linz GM. 2017. European Starlings. Wildlife Damage Management Technical Series. USDA, APHIS, WS National Wildlife Research Center. Fort Collins, CO. Available at https://digitalcommons.unl.edu/nwrcwdmts/13/.

Jenni L. 1982. Schweizerische Ringfunde von Bergfinken Fringilla montifringilla: Ein Beitrag zum Problem der Masseneinflüge. Ornithologischer Beobachter 79:265-272. Available at http:// www.ala-schweiz.ch/images/stories/pdf/ob/1982_79/OrnitholBeob_1982_79_265_Jenni.pdf.

Jenni L. 1984. Die Bedeutung der Masseneinflüge und Massenschlafplätze in der Winterökologie des Bergfinken: Fringilla montifringilla. $\mathrm{PhD}$ Thesis, Universität Basel.

Jenni L. 1987. Mass concentrations of Bramblings Fringilla montifringilla in Europe 1900-1983: their dependence upon beech mast and the effect of snow-cover. Ornis Scandinavica 18: 84-94. https://doi. org/10.2307/3676843

Jenni L. 1991. Microclimate of roost sites selected by wintering Bramblings Fringilla montifringilla. Ornis Scandinavica 22: 327-334. https://doi.org/10.2307/3676504

Jenni L. 1993. Structure of a Brambling Fringilla montifringilla roost according to sex, age and bodymass. Ibis 135: 85-90. https://doi. org/10.1111/j.1474-919X.1993.tbo2813.x

Jenni L \& Jenni-Eeiermann S. 1987. Body-weight and energy reserves of Bramblings in winter. Ardea 75: 271-284.

Jenni L \& Neuschulz F. 1985. Die Masseneinflüge von Bergfinken, Fringilla montifringilla, 1977/1978 und 1982/1983 in der Schweiz: Abhängigkeit von der Schneedecke und vom Nahrungsangebot. Ornithologischer Beobachter 82: 85-106.

Kamp J, Oppel S, Ananin AA, Durnev YA, Gashev SN, Hölzel N, Mishchenko AL, Pessa J, Smirenski SM, Strelnikov EG, Timonen S, Wolanska K \& Chan S. 2015. Global population collapse in a superabundant migratory bird and illegal trapping in China. Conservation Biology 29: 1684-1694. https://doi.org/10.1111/cobi.12537

Kestenholz M, \& Schaffner W. 1993. Masseneinflüge von Bergfinken Fringilla montifringilla ins Fricktal. Ornitologischer Beobachter 90: 297-299.

Khil L, Samwald O, Tiefenbach A, Tiefenbach M \& Pacher H. 2011. Der Massenschlafplatz von Bergfinken Fringilla montifringilla in Österreich im Winter 2008/2009. Limicola 25: 81-100.

Kjellén N. 2019. Sträckfågelräkningar vid Falsterbo hösten 2018. [Migration counts at Falsterbo in the autumn of 2018]. Pp 5-50 in Fåglar i Skåne 2018, Anser supplement 76 (Bentz P-G, Lundahl E, Ohlsson A \& Svensson T, eds). Skånes Ornitologiska Förening, Vellinge. Available at https://www.falsterbofagelstation.se/arkiv/ pdf/322.pdf.

Kjellén N, \& Lindström Å. 1993. Bergfinkens övervintringsstrategier samt några iakttagelser från en skånsk sovplats i januari-februari 1993. Anser 32: 187-199.

Lindström Å, Enemar A, Andersson G, von Proschwitz T \& Nyholm NEI. 2005. Density-dependent reproductive output in relation to a drastically varying food supply: getting the density measure right. Oikos 110: 155-163. https://doi.org/10.1111/j.0030-1299.2005.13828.x

Linz GM, Avery ML \& Dolbeer RA. 2017. Ecology and Management of Blackbirds (Icteridae) in North America. CRC Press, Boca Raton, FL. https://doi.org/10.4324/9781315156439

Lithner S. 1995. Två miljoner bergfink. Fåglar i Nordvästskåne 1995: 6-7.

Lowe S, Browne M, Boudjelas S \& De Poorter M. 2000. 100 of the world's worst invasive alien species: a selection from the global invasive species database. Vol 12. IUCN SSC Invasive Species Specialist Group, Auckland. Available at https://portals.iucn.org/library/ sites/library/files/documents/2000-126.pdf. 
Manikowski S. 1988. Aerial spraying of quelea. Tropical Pest Management 34: 133-140. https://doi.org/10.1080/09670878809371227

Martinek Langholz D. 2020. Comments in the thread "Kvækerfinker Kliplev. Årtoft Plantage Syd”, Facebook group Feltornitologen. Retrieved from https://www.facebook.com/groups/222495431241303/ permalink/1428791147278386/ on 3 April 2020.

Mathiasson S. 196o. Skånsk fågelvinter. Sveriges Natur 51: 2-8.

McWilliam AN \& Cheke RA. 2004. A review of the impacts of control operations against the red-billed quelea (Quelea quelea) on non-target organisms. Environmental Conservation 31: 130-137. https://doi.org/10.1017/So376892904001213

Møller AP \& Laursen K. 2019. The ecological significance of extremely large flocks of birds. Ecology and Evolution 9: 6559-6567. https://doi.org/10.1002/ece3.5234

Mühlethaler F. 1952. Beobachtungen am Bergfinken-Schlafplatz bei Thun 1950/51. Ornithologischer Beobachter 49: 173-181.

Murray GG, Soares AE, Novak BJ, Schaefer NK, Cahill JA, Baker AJ, Demboski JR, Doll A, Da Fonseca RR, Fulton TL, Gilbert MT, Heintzman PD, Letts B, McIntosh G, O'Connell BL, Peck M, Pipes M-L, Rice ES, Santos KM, Sohrweide AG, Vohr SH, Corbett-Detig RB, Green RE \& Shapiro B. 2017. Natural selection shaped the rise and fall of passenger pigeon genomic diversity. Science 358: 951-954. https://doi.org/10.1126/science.aaoo960

Nardin C \& Brauchle G. 1979. Un dortoir de Pinsons du Nord. Bulletin de la Société d'Histoire Naturelle du Pays de Montbéliard 1979: 89-111.

Nardin C \& Nardin G. 1985. Comportements alimentaires chez les Pinsons du Nord, Fringilla montifringilla, en hiver. Nos Oiseaux 38: 113-120.

Newton I. 1972. Finches. Collins, London.

Newton I. 1998. Population limitation in birds. Academic Press, London.

Newton I. 2006. Advances in the study of irruptive migration. Ardea 94: 433-46o. Available at http://www.globalraptors.org/grin/ researchers/uploads/302/irruptive.pdf.

Newton I. 2007. The migration ecology of birds. Academic Press, London.

Newton I. 2012. Obligate and facultative migration in birds: ecological aspects. Journal of Ornithology 153: 171-18o. https://doi.org/10.1007/ s10336-011-0765-3

Nilsson R. 1983. Om bergfinkens massbesök i Kågeröd vintern 1915-1916. Anser 22: 163-166.

Nilsson SG. 1979. Seed density, cover, predation and the distribution of birds in a beech wood in southern Sweden. Ibis 121: 177-185. https://doi.org/10.1111/j.1474-919X.1979.tbo496o.x
Schifferli A. 1953. Der Bergfinken-Masseneinfall (Fringilla montifringilla) 1950/51 in der Schweiz. Ornithologischer Beobachter 50: 65-89

Şekercioğlu $\mathrm{CH}$. 2006. Increasing awareness of avian ecological function. Trends in Ecology \& Evolution 21: 464-471. https://doi. org/10.1016/j.tree.2006.05.007

Sutter E. 1948. Der Bergfinken-Masseneinfall im Winter 1946/47 in der Schweiz und in Südwestdeutschland. Ornitologischer Beobachter 45: 98-106.

Svensson T. 2020. Bibliska mängder bergfink - en berättelse om bokollon, barrträd, bajs och beräkningar. Anser 59(3): 7-27.

SMHI (Swedish Meteorological and Hydrological Institute). 2020. Vintern 2020 - Ovanligt rekordrik vinter. Retrieved from https://www.smhi.se/klimat/klimatet-da-och-nu/arets-vader/ vintern-2020-ovanligt-rekordrik-vinter-1.155690.

Tout P. 2019. Mega flock of 5 million Brambling in Slovenia. Rare Bird Alert. Retrieved from https://www.rarebirdalert.co.uk/v2/ Content/Mega_flock_of_5_Million_Brambling_in_Slovenia. aspx?s_id=1054830233.

von Wühlisch G. 2008. EUFORGEN Technical Guidelines for genetic conservation and use for European beech (Fagus sylvatica). Bioversity International, Rome. Available at https://bit.ly/3sNbmd6.

Yésou P, Debout G, Erard C, Pons J-M \& Thibault J-C. 2014. Georges Hémery (1952-2013): Disparition d'un éminent biologiste des populations. Revue d'Écologie (la Terre et la Vie) 69: 356-359. Available at https://bit.ly/3dr1Cyp.

Zabala J, Zuberogoitia I, Belamendia G \& Arizaga J. 2012. Micro-habitat use by Bramblings Fringilla montifringilla within a winter roosting site: influence of microclimate and human disturbance. Acta Ornithologica 47: 176-181. https://doi. org/10.3161/000164512X662287

Zuberogoitia I, Martínez JE, Zabala J, Belamendia G \& Calvo JF. 2012. Solitary hunters sharing an abundant trophic resource: simultaneous hunting by raptors at a Brambling winter roost. Journal of Raptor Research 46: 318-322. https://doi.org/10.3356/JRR-11-74.1

Övergaard R. 2010. Seed production and natural regeneration of beech (Fagus sylvatica L.) in southern Sweden. PhD Thesis, Swedish University of Agricultural Sciences, Alnarp.

Övergaard R, Gemmel P \& Karlsson M. 2007a. Effects of weather conditions on mast year frequency in beech (Fagus sylvatica L.) in Sweden. Forestry 80: 555-565. https://doi.org/10.1093/forestry/ cpmozo

Övergaard R, Gemmel P \& Karlsson M. 2007b. Tätare och rikligare ollonår ökar chansen för lyckade bokföryngringar. Fakta Skog 13/2007. Available at https://pub.epsilon.slu.se/3582/1/FaktaSkog_13_2007. pdf. 


\section{Svensk sammanfattning}

Stora ansamlingar av fåglar, eller avsaknaden av sådana, är ett fenomen kopplat till födotillgång och populationsstorlekar och kan därför ge viktig information om tillståndet i vår miljö. Därtill är stora mängder fåglar inte sällan en källa till betydande konflikter med människan. Till exempel blir tiotals miljoner blodnäbbsvävare Quelea quelea årligen förgiftade eller sprängda (!) på grund av deras påverkan på jordbruket i subsahariska Afrika. Rödvingetrupialer Agelaius phoeniceus, båtstjärtar Quiscalus sp. och kostarar Molothrus sp. kan efter häckningssäsong samlas i miljoner och är föremål för omfattande bekämpningsinsatser, då de årligen skapar stor frustration hos amerikanska odlare. Staren Sturnus vulgaris, en av tre fågelarter på IUCNs lista över världens hundra värsta invasiva arter, är ett annat intressant exempel. Arten kan samlas i miljonantal och betraktas som ett allvarligt problem på flera kontinenter, bland annat på grund av smittspridning och inverkan på bäroch fruktodlingar. Adekvat skattning av antal är central i sammanhanget, oavsett om det handlar om skador på odlingar eller en bedömning av populationsstorlek: det spelar en avgörande roll om det är en eller tio miljoner faglar man har framför sig. Då antalsuppskattning är erkänt svårt, speciellt när det gäller stora mängder fåglar, finns det ett stort värde i att titta närmare på just detta.

Detta arbete är en djupdykning i fallet bergfink Fringilla montifringilla (figur 1). Få fågelarter samlas i miljoner, men bergfinken är en av dessa. Det är också den art som samlas i allra störst antal på europeisk mark. Till skillnad från staren, som årligen ses i stora antal på många platser i Europa, uppträder bergfinken i stora antal nästan uteslutande under bokollonår (för ett intressant undantag, se avsnittet om en ansamling $i$ majsdistrikt i Frankrike på 1960-talet). Bakgrunden till arbetet är en vilja att ge ett historiskt och internationellt perspektiv på de stora mängder bergfinkar som övervintrade i Sverige på grund av det makalösa bokollonår som inföll 2019. Enligt Sven G. Nilsson vid Lunds Universitet, som sedan 1971 följt bokollonproduktionen i Sverige, överträffar bokollonmängden under 2019 samtliga tidigare år i serien. Händelsen har sin bakgrund i den extremtorra och bekymmersamma sommaren 2018, och en koppling till de alltmer påtagliga klimatförändringarna ligger nära till hands.

Att många bergfinkar valde att övervintra i Sverige vintern 2019-2020 blev tydligt i december 2019 då bland annat uppskattningsvis 4-8 miljoner individer passerade Båstad 22 december (figur 3, video 1). Sovplatsen hittades 4 januari 2020 och omfattade knappt sex hektar granplantering på Hallandsåsens sydsluttning, strax norr om Rössjöns norra strand (figur 4, video 1). Sovplatsen bestämdes utifrån spillningstäcke och bestod av ungefär lika stora delar 31-årig (figur 5) respektive 39-årig plantering, omfattande uppskattningsvis 7000 träd. Att räkna antalet fåglar vid sovplatsen visade sig vara lättare sagt än gjort, och som antalsuppskattning används därför siffran från Båstad (detaljer kring denna siffra finns i den engelska huvudtexten samt i en längre svensk text publicerad i Anser, se Svensson 2020).

Riktigt stora ansamlingar bergfinkar hör inte till vanligheterna i Sverige, och undertecknad har i litteraturen endast funnit tre omskriva sovplatser. De som studerats och beskrivits i detalj är blott den vid Kågeröd 1915-1916 och den vid Västersjön 1992-1993. Bergfinkens huvudsakliga övervintringsområde återfinns i det bokskogsrika Centraleuropa (figur 2), och det är från denna region de flesta skildringar av miljonansamlingar av bergfink har sitt ursprung. En närmare titt på alla dessa redogörelser visar tydligt att uppgifter kring antal och sovplatsarealer spretar ordentligt, och siffrorna är inte sällan dåligt eller obefintligt motiverade (tabell 1). De högsta siffrorna härrör från Schweiz och Frankrike, varav de två mest extrema är rapporterna om 70 miljoner från Thun i Schweiz vintern 1950-1951 samt 120 miljoner från Etobon i Frankrike 1977-1978 (tabell 1). Dessa siffror är dock baserade på bristfälligt motiverade antaganden om flockvolym (bredd, höjd och längd) och täthet (fåglar per kubikmeter), storheter som i sig är mycket svåruppskattade. Siffran 70 miljoner är flitigt omnämnd i litteratur och media men har av Lukas Jenni - den forskare som lagt mest kraft på att studera bergfinkens vintervanor - dömts ut som en ordentlig överskattning (Jenni menar att det till och med kan röra sig om en överskattning på mer än en faktor tio). Undertecknad instämmer i Jennis kritik om att det är synnerligen vanskligt att uppskatta flockarnas täthet, bredd och höjd och att en bättre väg framåt är att uppskatta antal via flödet av fåglar per tidsenhet (intervallskattning). Baserat på studier där sovplatsens areal bestämts via spillningstäcke och där man skattat antal via flöde kan man möjligen skönja att fågeltät- 
heten för en sovplats ligger på, i storleksordningen, en miljon fåglar per hektar (figur 9). Detta ska dock ses som en grov skattning i behov av ytterligare verifiering. De största sovplatserna rapporteras omfatta över tio hektar och visst stöd finns för ansamlingar upp till kring 15 miljoner fåglar. Flest kan möjligen ha funnits i sydvästra Frankrike i slutet av 1960-talet, då miljoner bergfinkar årligen nyttjande samma sovplats och födosökte på majsfält. Till skillnad från andra kända sovplatser, vilka utgjorts av barrträd och använts ett enstaka år, utgjordes denna sovplats av vintergrön järnek Ilex aquifolium i kombination med ek Quercus sp. med kvarsittande döda (marcescenta) löv. Vissa bedömare menar att denna sovplats till och med kan ha omfattat upp till 20 miljoner faglar, men i och med förändrade lantbruksmetoder ebbade detta övervintringsfenomen ut under 1970-talet.

Givet de stora svårigheterna i att uppskatta antalet för stora ansamlingar fåglar bör man alltid se på miljonsiffror med försiktighet och noggrant granska underlaget, oavsett om det handlar om bergfinkar, starar, vandringsduvor Ectopistes migratorius eller blodnäbbsvävare. I fallet bergfink har, som diskuterats i föreliggande artikel, även etablerade ornitologer visat sig vara oense om en faktor tio. Ur en kritisk synvinkel bör nog miljoner tolkas som många i de fall där gediget underlag saknas.

Vad gäller bergfinksansamlingar finns fortfarande mycket att reda ut, och följande råd ges till den som får chansen att studera en sovplats:

- Försök att räkna flödet av fåglar vid morgonlyft eller inflygning. Undvik att skatta antal via flockvolym och täthet då detta är synnerligen svårt.

- Bestäm sovplatsens area genom att mäta den area som är täckt av ett ordentligt lager spillning. Mät arean med hjälp av ett kartverktyg som kan räkna ut arean utifrån en noggrant uppritad gränslinje (t. ex. Google Maps).

- Dokumentera träden inom sovplatsen (art, ålder, höjd, avstånd mellan träd, totalt antal).

- Försök uppskatta antalet fåglar per träd. Detta kan förslagsvis göras nattetid med hjälp av t. ex. värmekamera.

- Om fåglar tros sova även i kala lövträd, bekräfta detta med t. ex. värmekamera under natten. Bergfinkarna rör sig även efter mörkrets inbrott och belägg för att nattkvist tas även $i$ kala lövträd runt sovplatser i barrträdsdungar är av intresse.

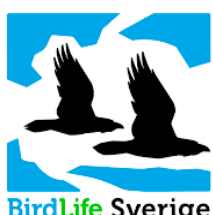

Ornis Svecica (ISSN 2003-2633) is an open access, peer-reviewed scientific journal published in English and Swedish by BirdLife Sweden. It covers all aspects of ornithology, and welcomes contributions from scientists as well as non-professional ornithologists. Accepted articles are published at no charge to the authors. Read papers or make a submission at os.birdlife.se.

Ornis Svecica (ISSN 2003-2633) är en fritt tillgänglig granskad vetenskaplig tidskrift som ges ut på svenska och engelska av BirdLife Sverige. Den täcker ornitologins alla områden och välkomnar bidrag från såväl forskare som icke-professionella ornitologer. Accepterade uppsatser publiceras utan kostnad för författarna. Läs uppsatser eller skicka in ditt bidrag på os.birdlife.se. 